\title{
Distribution of Nutrients and Changes in Phytoplankton Composition in a Tropical Mesotidal Estuary, Northeastern Brazil
}

\section{Andréa Shirley Xavier da Silva, Carlos Noriega*, Maria Luise Koening, Manuel Flores Montes, Moacyr Araujo}

Departamento de Oceanografia, Universidade Federal de Pernambuco-UFPE, Recife, Brasil

Email: *carlos.delnor@gmail.com

How to cite this paper: da Silva, A.S.X., Noriega, C., Koening, M.L., Montes, M.F. and Araujo, M. (2017) Distribution of Nutrients and Changes in Phytoplankton Composition in a Tropical Mesotidal Estuary, Northeastern Brazil. Open Journal of Ecology, 7, 460-494.

https://doi.org/10.4236/oje.2017.77032

Received: April 27, 2017

Accepted: July 15, 2017

Published: July 18, 2017

Copyright $\odot 2017$ by authors and Scientific Research Publishing Inc. This work is licensed under the Creative Commons Attribution International License (CC BY 4.0).

http://creativecommons.org/licenses/by/4.0/

\begin{abstract}
Abiotic parameters and phytoplankton were collected during 2010 and 2011 with the purpose of describing the phytoplankton distribution and the environmental characteristics. The diatoms were the most representative group in terms of species richness; in terms of density, the Cyanobacteria were more representative. Diversity and equitability were generally low in the estuary due to the dominance of Microcystis aeruginosa, an opportunistic and potentially toxic species of Cyanobacteria. The estuarine region is strongly impacted by high pollutant loads, especially nitrogen and phosphate compounds. Historical series of Apparent Oxygen Utilization (AOU) showed negative trends associated with changes in the estuarine system. The main biological components changed through 1999-2011 period. The dominance of the species changed from the Bacillariophyta in previous studies to the Cyanobacteria in our study. The species Microcystis aeruginosa, through its high density, dominance and frequency of occurrence, was the key species in the area.
\end{abstract}

\section{Keywords \\ Coastal Environment, Nutrients, Biodiversity, Phytoplankton, Tropical Estuary}

\section{Introduction}

Estuaries are dynamic systems characterized by gradients of salinity, turbidity, temperature, nutrient concentration and organic matter [1]. Approximately $60 \%$ of the large cities distributed around the Earth are located near estuarine regions, making these environments of great importance for the planet. These regions are 
the main suppliers of nutrients to the coastal regions, since they receive and concentrate the material originating from their drainage basin and can receive significant contributions from anthropic action [2]. The spatial connection with this region is the continental shelf, which acts as a final recipient of water and materials from the continent that are transported by the discharge of rivers and estuaries. The meeting of low-salinity continental waters with coastal waters defines regions where there are high gradients of properties, the so-called front zones [3].

Currently, the coastal zones, due to population and urban growth, are the areas most impacted by anthropic action and consequently are the areas most subject to algal blooms due to eutrophication processes resulting from domestic effluents and increases in organic matter [4]. The ability to respond quickly to spatial and temporal fluctuations of environmental conditions makes the phytoplankton community a good bioindicator of changes in environments arising from natural causes or as a result of human actions [5].

The contamination of an aquatic ecosystem is manifested in phytoplankton populations by the development of two inverse and simultaneous phenomena: on the one hand, the emergence and proliferation of selective species and on the other hand, the disappearance of part or all of the original population of the environment. To determine the biological quality of water, the populations can be used as a reference frame in which the presence or absence of organisms is fundamental or to verify the existence of organisms that are indicative or characteristic of some type of contamination [6]. In estuarine ecosystems, planktonic populations are known to be influenced by spatio-temporal variations in physico-chemical parameters and tidal dynamics [7].

Phytoplankton is the main primary producer of the coastal environments, being responsible for the beginning of the flow of matter and energy of the trophic network of these environments; contributing to their fertilization; and directly supporting the herbivores and indirectly the animals of the higher trophic levels, including economically important species [8].

Works about phytoplankton in estuarine ecosystems in the northeastern region of Brazil, and especially in the state of Pernambuco, are well known in [9]-[22]. Work in coastal areas is still insufficient ([23] [24] [25] [26]) and, specifically for the coastal areas adjacent to the estuary of the Jaboatão River, are non-existent.

The Jaboatão River Basin, located mostly in the Metropolitan Region of Recife (RMR), presents problems common to Brazilian urban water basins: the degradation of natural resources through inadequate land occupation and use; pollution caused by the release of domestic wastes and industrial effluents; and high population density. This estuary represents one of the most vulnerable areas in the RMR to the degradation provoked by the increase of urban pressure and real estate (1100 inhabitants $/ \mathrm{km}^{-2}$ ) [19]. These factors constitute a high degree of risk to the continuity of the existence of this environment. The present work aimed to identify the phytoplankton community, correlating its density and environ- 
mental characteristics (nutrients, DO) in the estuary of the Jaboatão River as well as in its adjacent platform in the area under the influence of the estuarine plume.

\section{Materials and Methods}

\subsection{Study Area}

The Jaboatão watershed, located in northeastern Brazilin Pernambuco State $\left(8^{\circ} 00^{\prime} \mathrm{S}-8^{\circ} 14^{\prime} \mathrm{S}\right.$ and $\left.34^{\circ} 50^{\prime} \mathrm{W}-35^{\circ} 15^{\prime} \mathrm{W}\right)$, is $413 \mathrm{~km}^{2}$ in area and $75 \mathrm{~km}$ in length. The river crosses the RMR, and the mouth is on the Atlantic Ocean (Figure 1).

The climate is typically tropical, hot and humid. The air temperature is $26^{\circ} \mathrm{C} \pm$ $2.8^{\circ} \mathrm{C}$, and the mean annual precipitation and evaporation are approximately 1.5 and $1.2 \mathrm{~m} \cdot \mathrm{yr}^{-1}$, respectively [27]. The rainfall regime is subdivided into two welldefined periods: the dry season (September-February), when precipitation is exceeded by evaporation; and the rainy season (March-August), when rainfall dominates evaporation (Figure 2). The estuary extends for approximately $13 \mathrm{~km}^{2}$, with an average depth of $2.6 \mathrm{~m}$ [19] [28] [29] (Figure 1). The drainage basin includes areas originally covered by the Atlantic Rain Forest and is presently occupied by sugar cane and high-density populated areas (1100 inhabitants $\mathrm{km}^{-2}$ ) [19] [30]. Despite the deforestation of the margins and the large volume of industrial and domestic effluents it receives, the estuary itself is surrounded by relatively well-preserved and highly productive mangrove forests. Organic matter

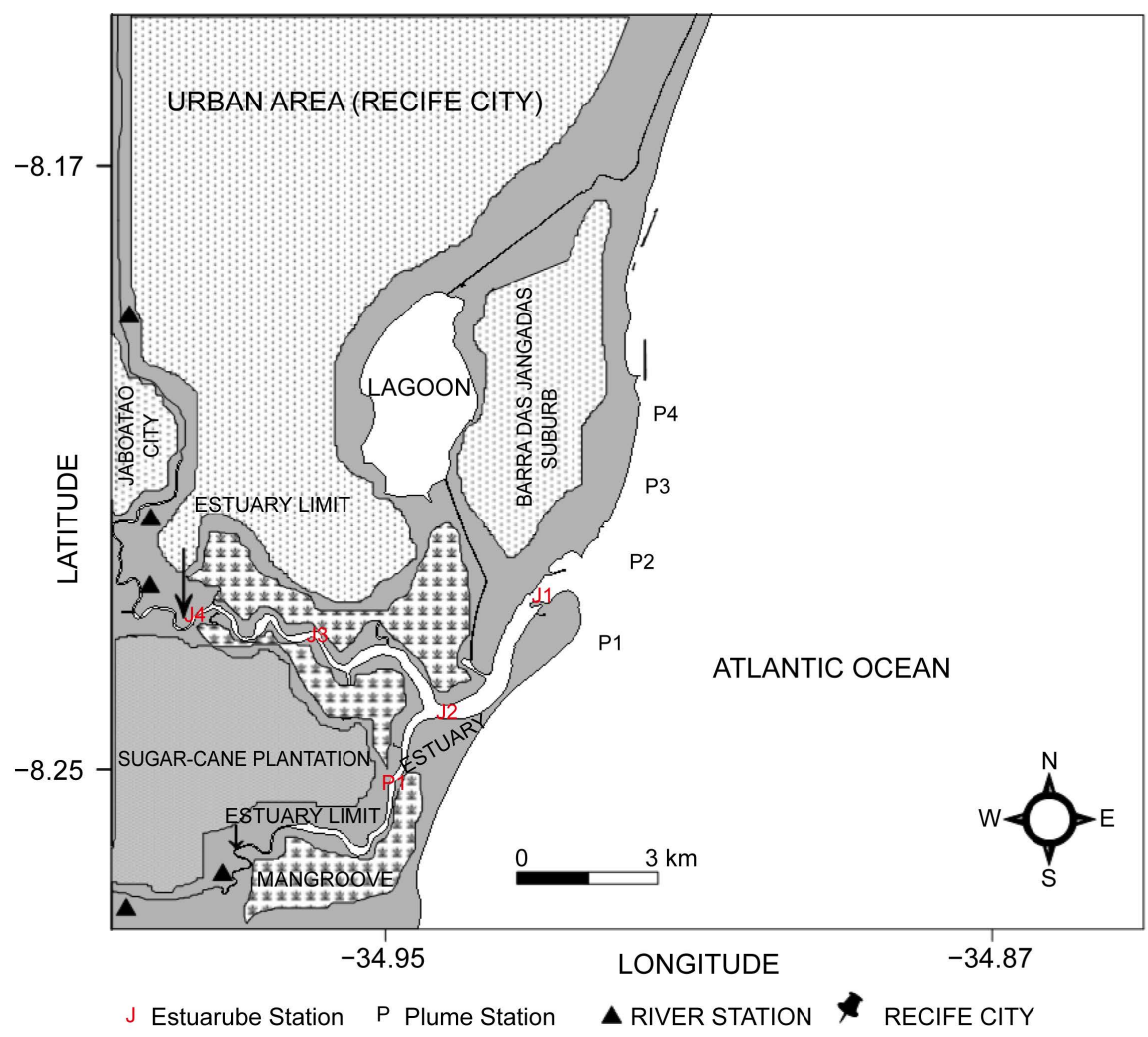

Figure 1. Sampling stations located in the estuary and plume of the Jaboatão River (northeastern Brazil). 


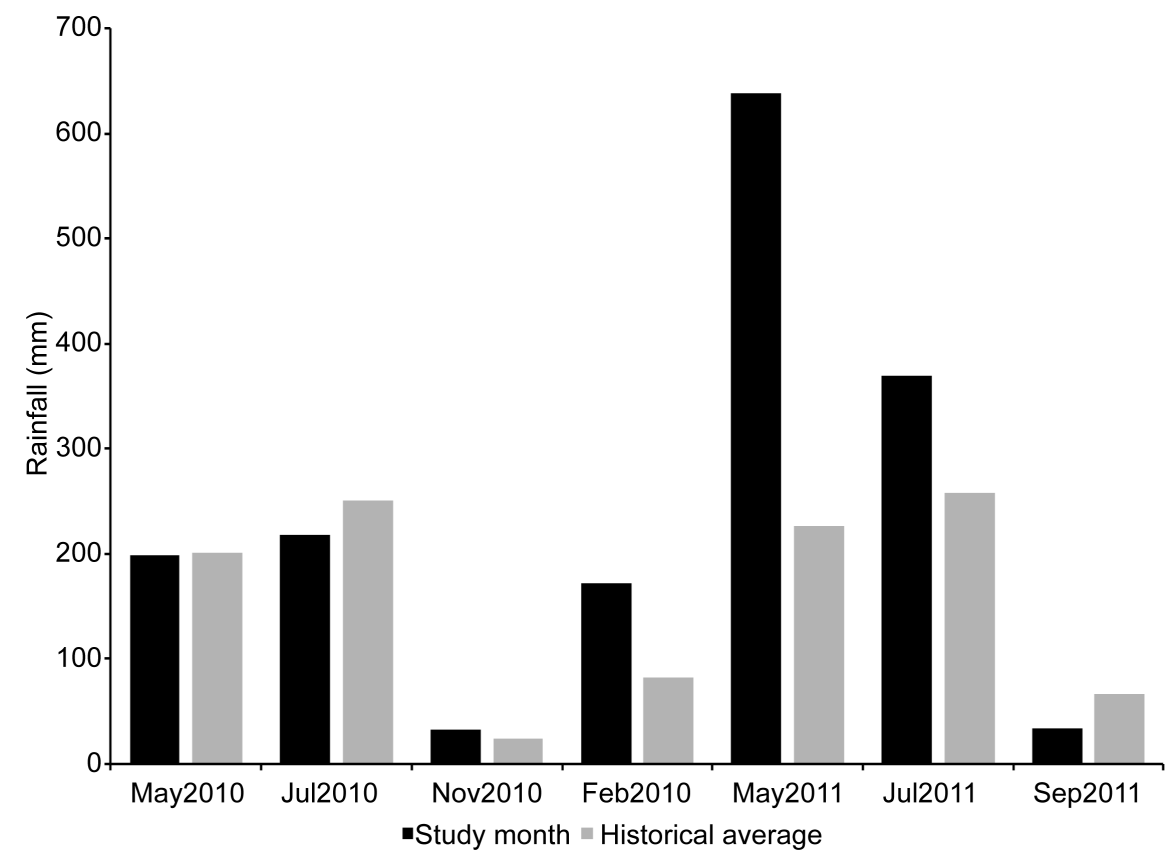

Figure 2. Climatological series of precipitation (1981-2011) for the study area (source: INMET).

pollution by the sugar-cane agro industry increases substantially during the harvest and milling season, which is from September to February. Environmental state agency reported a high BOD of $69.6 \mathrm{mg} \cdot \mathrm{l}^{-1}$ in the harvest periods [29]. The polluting organic load sources are represented mainly by domestic sewage in the Jaboatão River (14.46 t BOD d $\mathrm{d}^{-1}$ ) [31]. Algal blooms are now more frequent during the year and consist of several species of Cyanophyceae, Oscillatoria sp. and Euglena sp. (Euglenophyta), suggesting some degree of permanent impact on the environment [28]. The river runoff is strongly controlled by rainfall (Figure 2), with an average discharge of $2-10 \mathrm{~m}^{3} \cdot \mathrm{s}^{-1}$ (annual average) [29] [32] [33]. The tidal regime is semidiurnal, with mean amplitude of $1.3 \mathrm{~m}$ (neap tides) and $1.8 \mathrm{~m}$ (spring tides) [27]. The estuary is well mixed, being classified as type 1 with an absence of vertical stratification [27] [29].

\subsection{Sampling and Analysis}

The samples were collected in a longitudinal profile in the Jaboatão River estuary, covering the marine area (estuarine plume) through four stations in the estuary and four in the plume (Figure 1). Samples were taken during the dry (November 2010, February 2011 and September 2011) and the rainy seasons (May 2010, July 2010, May 2011 and July 2011), comprising a total of seven campaigns. For this study, we divided the estuarine region into 8 segments (every 5 units of salinity) based on the longitudinal saline gradient classification proposed by [34]. The estuarine limit with the plume region was calculated based on the average saline in the plume samplings.

The temperature and salinity (conductivity) were measured using a CTD (SeaBird Electronics SBE911plus; Sea-Bird Scientific Inc. ${ }^{\oplus}$. The salinity was also 
verified against the chlorinity, which was determined using $\mathrm{AgNO}_{3}$ titration [35]. The local depth was determined by digital echo sounder, mark LCD-resolution: $0.1 \mathrm{~m}$ ) and depth of visual disappearance of the Secchi disk (water transparency).

Water samples were collected with Van Dorn bottles for further analysis of dissolved oxygen (DO) and nutrients. The $\mathrm{pH}$ was measured on the NBS scaleon board after sample collection using a $\mathrm{pH} / \mathrm{ion}$ analyser 350 and a Ross combination electrode (Orion ${ }^{\oplus}$ ). The precision and the accuracy of the $\mathrm{pH}$ measurements were \pm 0.005 units and $0.1 \%$, respectively. DO was analysed by the Winkler method [36], with a precision of $\pm 1.3 \mu \mathrm{M}$. The relative oxygen saturation (\%) in the water was calculated using the following equation for temperatures between $0^{\circ} \mathrm{C}$ and $40^{\circ} \mathrm{C}$ and salinities between 0 and 40 :

$$
\%=\frac{\mathrm{DO}}{\mathrm{DO}^{*}} \times 100
$$

where $\mathrm{DO}$ is the oxygen concentration in the sample and $\mathrm{DO}^{*}$ is the oxygen solubility in the water at the same temperature and salinity using the UNESCO tables [37].

Apparent oxygen utilization (AOU) was calculated according to [38].

The dissolved inorganic nutrients, ammonia + nitrite + nitrate (DIN), phosphate (DIP), were analysed according to [36] after filtration of the samples using Whatman ${ }^{\oplus} \mathrm{GF} / \mathrm{C} 0.47$-mm glass fibre filters. The precision was $\pm 0.02 \mu \mathrm{mol}$ for nitrate, $\pm 0.02 \mu \mathrm{mol}$ for nitrite, $\pm 0.02 \mu \mathrm{mol}$ for ammonia, and $0.01 \mu \mathrm{mol}$ for phosphate. The accuracy was $\pm 2 \%$ for DIP, $\pm 3 \%$ for nitrate and nitrite, and $\pm 5 \%$ for ammonia.

The samples for the phytoplankton study were collected with Niskin oceanographic bottles and later fixed with Lugol solution. The analyses were performed according to the sedimentation method of Utermöhl [39] [40] [41], and counts were performed under a ZEISS Axiovert inverted microscope. Additional information on the phytoplankton identification methodology can be seen in the supplementary material.

\subsection{Meteorological Data}

The rainfall data were obtained through the website of the Pernambuco State Agency for Water and Climate (APAC) and the National Institute of Meteorology (INMET).

\subsection{Statistical Analyses}

The similarity between the biological samples was evaluated based on the BrayCurtis coefficient, using the data based on the relative abundance, transformed into the fourth root, with amalgamation method by the group mean. The similarity between the abiotic samples was also evaluated with the relative abundance data transformed into the fourth root, by the mean of the group but based on the Euclidean distance. The Principal Components analysis (PCA) was based on the 
hydrological parameters and the phytoplankton cell density, applying the Pearson's moment-to-product correlation coefficient, with the self-value of the main components and the auto-vector being extracted. The trend of the time series was obtained through the Mann-Kendall test and Linear Regression. For the two tests, the programs PRIMER $6^{\bullet}$ (Plymouth Routines in Multivariate Ecological Research) and XLSt at $2010^{\circ}$ were used, respectively.

\section{Results}

\subsection{Climatology and Physical Factors}

The total monthly rainfall ranged from $32.4 \mathrm{~mm}$ in November 2010 to $638.6 \mathrm{~mm}$ in May 2011. The typical dry season months had the lowest indexes, according to the historical values of the study region (Figure 3(a)). The study period did not show significant differences with the values recorded historically for the same months ( $t$-test; $p$ : $0.38 ; \alpha: 0.05)$.

The salinity in the estuary ranged from 0.04 to 27.54 , from freshwater to polyhaline, presenting the highest values mainly in the dry period (Figure 3(b)). In the dry period, the variability was lower in relation to the rainy season, showing significant differences between the two periods ( $t$-test, $p: 0.05, \alpha: 0.05$ ).

In the estuary, the thermal amplitude and its average value were $2.5^{\circ} \mathrm{C}$ and $28.0^{\circ} \mathrm{C} \pm 1.0^{\circ} \mathrm{C}$, respectively, while in the plume region, the amplitude was $3^{\circ} \mathrm{C}$ and the average $28.5^{\circ} \mathrm{C} \pm 0.8^{\circ} \mathrm{C}$. The studied area showed significant differences ( $t$-test, $p: 0.04 ; \alpha: 0.05$ ), which can also be observed in Figure $3(\mathrm{c})$ and Figure $3(d)$ through the salt gradient. Seasonal analyses also showed statistically significant differences between the dry and the rainy season ( $t$-test; $p: 0.0001 ; \alpha$ : 0.05).

As shown in Figure 3(c) and Figure 3(d), the estuarine gradient also showed thermal variations throughout the year, which are characteristic in tropical coastal areas. The mean amplitude between the climatic periods was $1^{\circ} \mathrm{C}$ (Figure 3 (c): $28.8^{\circ} \mathrm{C}$; Figure $3(\mathrm{~d}): 27.8^{\circ} \mathrm{C}$ ).

The local depth in the estuary presented an average value of $3.0 \pm 2.0 \mathrm{~m}$, while in the plume region, the mean depth was $11.5 \pm 2.0 \mathrm{~m}$. The water transparency was also lower in the estuary $(0.53 \pm 0.2 \mathrm{~m})$ than in the plume region, where the Secchi disc recorded an average value of $2.23 \pm 1.4 \mathrm{~m}$ (Figure 3(e) and Figure $3(\mathrm{f})$ ). In the estuary, the highest values of transparency occurred in the dry period (September to February), a season of lower fluvial contribution and lower values of rainfall. The values observed between the dry and rainy periods did not show significant differences ( $t$-test; $p: 0.37 ; \alpha: 0.05)$.

\subsection{Chemical Factors: $\mathrm{pH}$ and Oxygen}

The $\mathrm{pH}$ values recorded in the estuarine area showed a range of 6.41 to 8.36 , while in the plume region, the values ranged from 7.76 to 8.92 . Statistical analysis showed significant differences between the two regions ( $t$-test; $p$ : $0.0001 ; \alpha$ : $0.05)$. The $\mathrm{pH}$ values were always lower in regions near the river and did not 


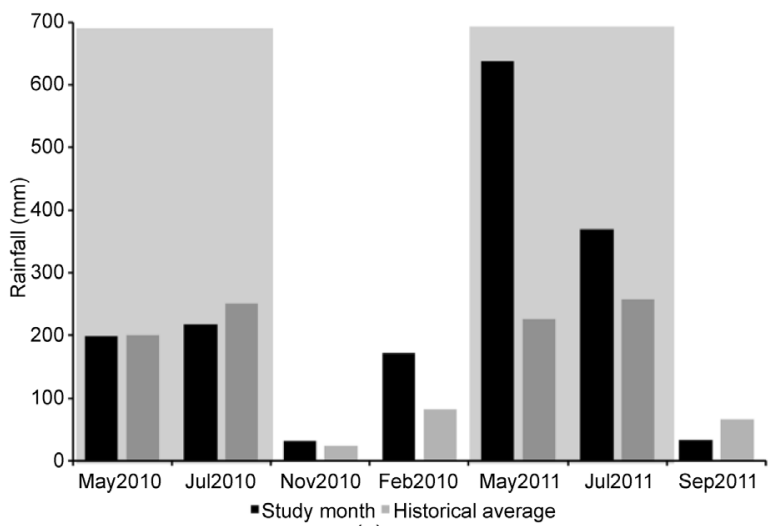

(a)

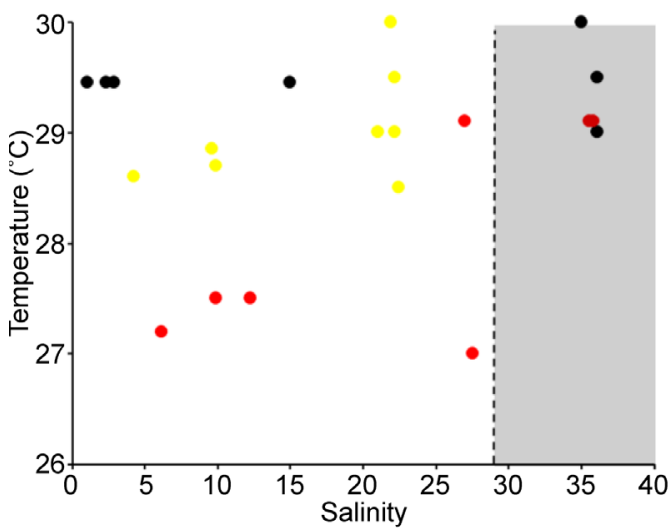

(c)

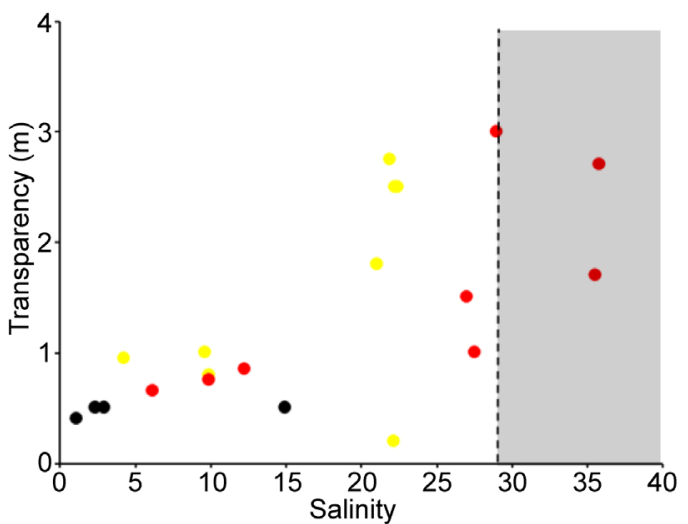

(e)

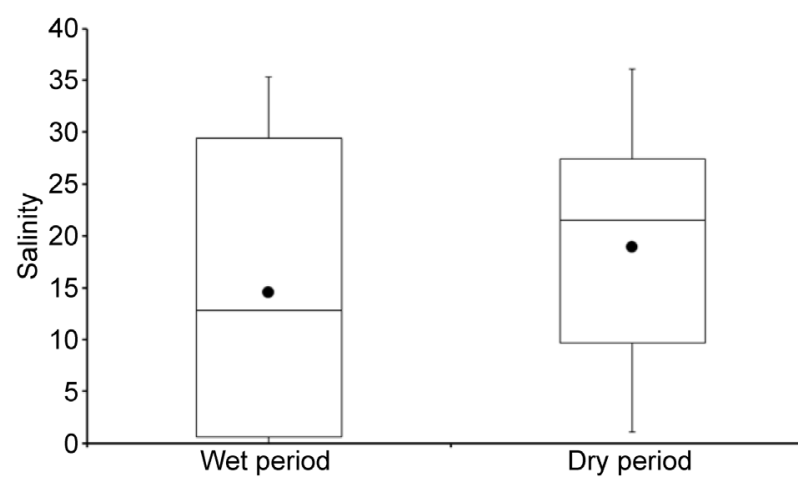

(b)
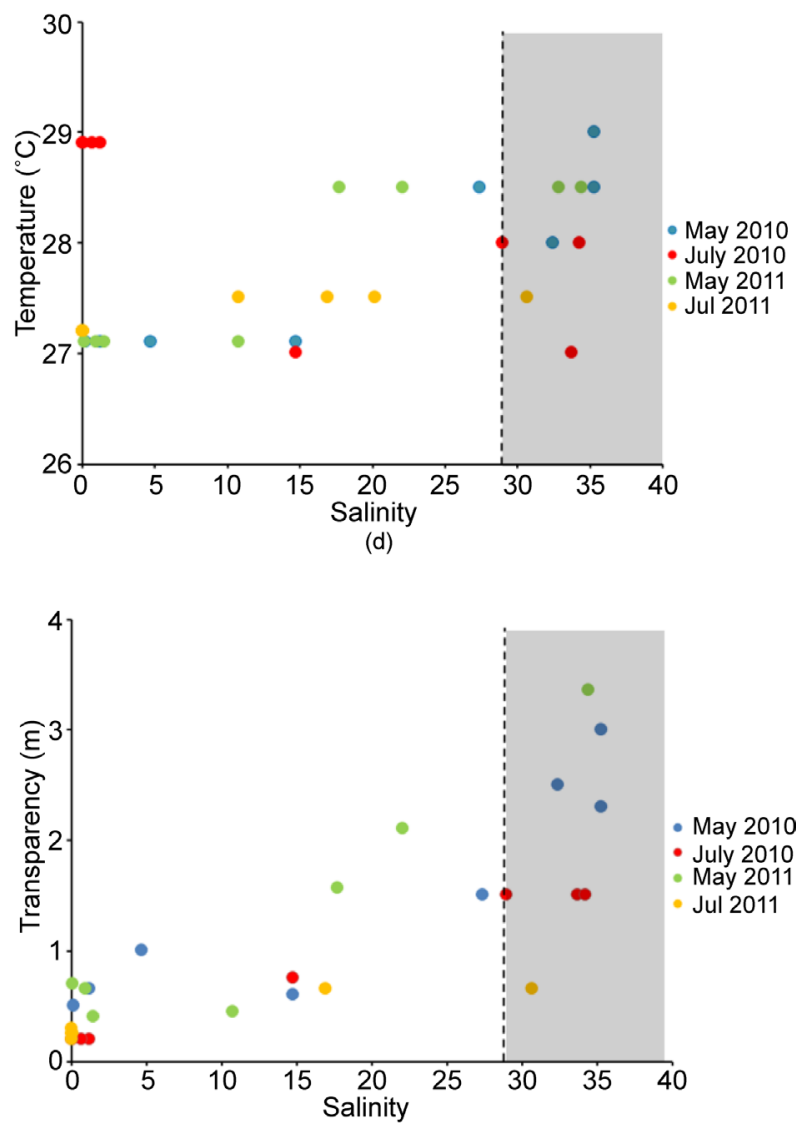

(f)

Figure 3. Rainfall (study period and historical average). Grey region indicate wet period (a); salinity (b); surface temperature $\left({ }^{\circ} \mathrm{C}\right)$ of the water through the salt gradient (c)-(d) and transparency (m) in the estuary and plume of the Jaboatão River (e)-(f). The dotted line indicates the mean salinity value for the plume region. In Figure 3(b), black circles indicate the mean and the horizontal line indicates the median.

show significant differences ( $t$-test; $p: 0.82 ; \alpha: 0.05)$ between the dry and the wet period (Figure 4(a) and Figure 4(d)).

DO in the estuary presented low levels, with a minimum of anoxia and a maximum of $4.1 \mathrm{ml} \cdot \mathrm{L}^{-1}$; the mean value in the estuarine area was $1.6 \mathrm{ml} \cdot \mathrm{L}^{-1}$, while in the plume region, the mean value was $4.4 \mathrm{ml} \cdot \mathrm{L}^{-1}$. DO concentrations showed significant differences between the estuarine area and the plume region 
( $t$-test; $p$ : $0.0001 ; \alpha: 0.05)$. During climatic periods in the study region, $50 \%$ of the samples showed concentrations below the limit indicated by CONAMA (3.5 $\mathrm{ml} \cdot \mathrm{L}^{-1}$; law decree 357, 2005) [42] (Figure 4(c), Figure 4(d); red line). The oxygen saturation (\%) followed the same pattern as DO, with a minimum of $0 \%$, a maximum of $85.65 \%$, and an average of $30 \%$. In the plume region, the oxygen saturation showed an average of $95.45 \%$, with a minimum of $78.46 \%$ and a maximum of $110.5 \%$.

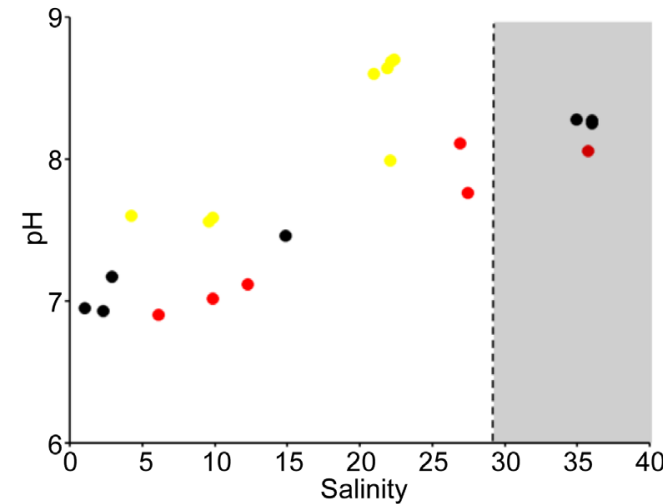

(a)

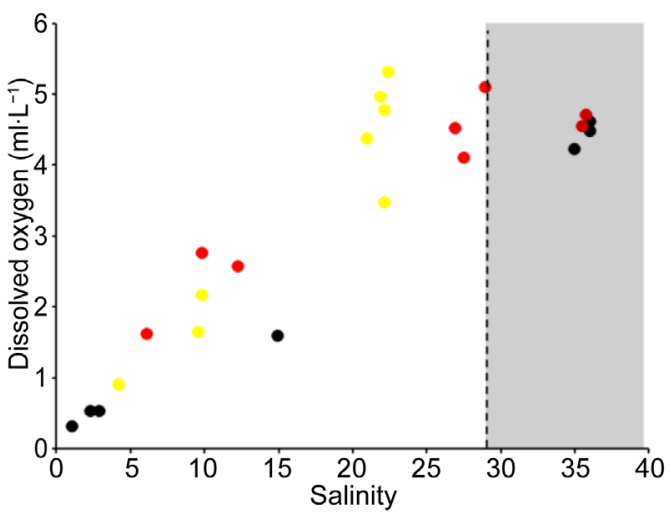

(c)

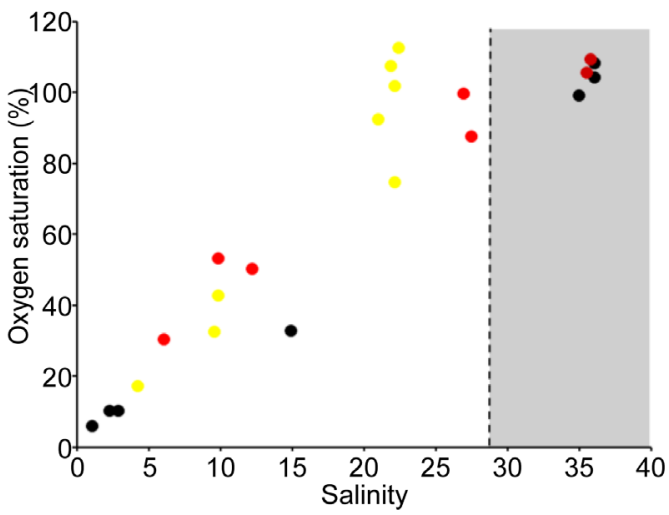

(e)

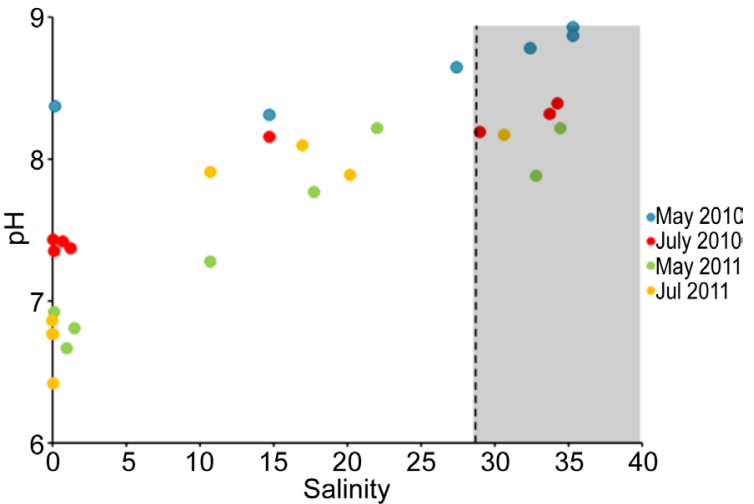

(b)

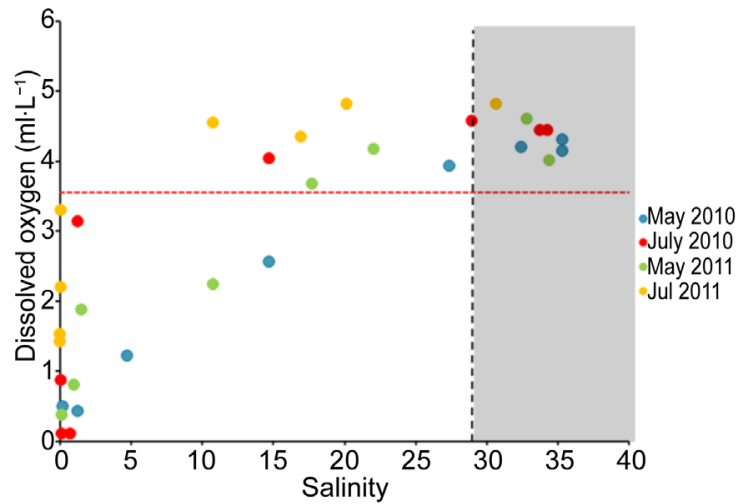

(d)
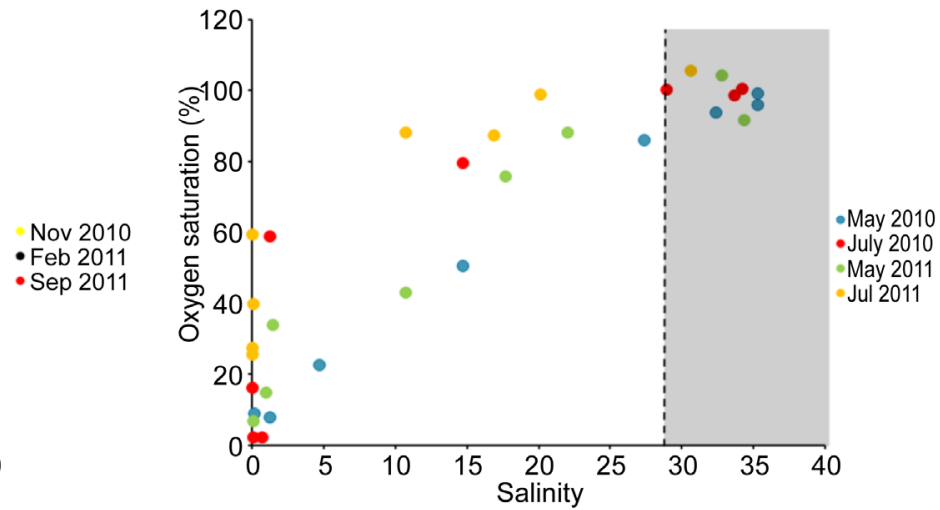

(f)

Figure 4. Surface $\mathrm{pH}$ of the water through the salt gradient (a)-(b), dissolved oxygen (c)-(d) and oxygen saturation rate (e)-(f) in the estuary and plume of the Jaboatão River. The red line indicates the limit established by the CONAMA 357 legislation. The dotted line indicates the mean value of salinity in the pen region. Grey area corresponds to plume region. Average and standard deviation for the dry and wet period are also shown. 


\subsection{Chemical Factors: Nutrients}

Ammonia showed a mean of $2.70 \mu \mathrm{mol} \cdot \mathrm{L}^{-1}$, with a minimum of $0.05 \mu \mathrm{mol} \cdot \mathrm{L}^{-1}$, presenting a peak of $14.29 \mu \mathrm{mol} \cdot \mathrm{L}^{-1}$ in May of 2010 and the lowest concentrations in November. Spatial variations showed significant differences between estuarine and plume regions ( $t$-test; $p: 0.0001 ; \alpha$ : 0.05) (Figure 5(a), Figure $5(\mathrm{~b}))$.

Nitrate concentrations varied between $0.58 \mu \mathrm{mol} \cdot \mathrm{L}^{-1}$ and $32.0 \mu \mathrm{mol} \cdot \mathrm{L}^{-1}$, with higher values in February and September (dry period), but $~ 90 \%$ of the observations occurred below $9 \mu \mathrm{mol} \cdot \mathrm{L}^{-1}$. The spatial gradient showed significant differences between the two regions ( $t$-test; $p$ : 0.0001; $\alpha$ : 0.05) (Figure 5(c), Figure $5(d))$.

The nitrite varied from $0.05 \mu \mathrm{mol} \cdot \mathrm{L}^{-1}$ to $3.82 \mu \mathrm{mol} \cdot \mathrm{L}^{-1}$, with the highest concentrations in November, and showed an increasing downstream-upstream gradient (Figure 5(e), Figure 5(f)). Spatial variations were observed between the estuarine and plume regions ( $t$-test; $p: 0.0001 ; \alpha: 0.05$ ).

The phosphate showed a minimum concentration of $0.27 \mu \mathrm{mol} \cdot \mathrm{L}^{-1}$ and a maximum of $9.46 \mu \mathrm{mol} \cdot \mathrm{L}^{-1}$, with an increasing downstream-upstream gradient. In the plume region, the concentrations were $<1 \mu \mathrm{mol} \cdot \mathrm{L}^{-1}$ (Figure $5(\mathrm{~g}$ ), Figure $5(\mathrm{~h})$ ). The spatial variations showed significant differences between the estuary and the plume ( $t$-test; $p: 0.0001 ; \alpha: 0.05)$.

Silicate showed higher concentrations principally in the estuarine region. The higher concentrations were registered in May (wet period), whereas the lower values were observed in February. The estuary and plume showed significant differences ( $t$-test; $p$ : 0.0001; $\alpha: 0.05)$.

\subsection{Biological Factors: Phytoplankton and Apparent Oxygen Utilization (AOU)}

The phytoplankton community in the studied areas consisted of 80 taxa, represented by seven phyla: Bacillariophyta (55\%), Miozoa (21\%), Cyanobacteria (11\%), Euglenophyta (5\%), Chlorophyta (4\%), Charophyta (3\%) and Ochrophyta (1\%). The phyla Bacillariophyta and Miozoa characterized the planktonic flora in $76 \%$ of the floristic diversity. The diatoms were more representative, presenting 4 classes, 22 orders and 26 families. Dinoflagellates had the secondhighest representation, with 1 class, 5 orders and 8 families, with emphasis on the genera Protoperidinium and Prorocentrum, with five taxa each. Cyanobacteria were represented by 1 class, 3 orders and 5 families (Table S1; Supplementary material).

The Bacillariophyta and Cyanobacteria groups showed different spatial distributions. Bacillariophyta did not show significant differences between the estuarine and plume regions ( $t$-test; $p: 0.24 ; \alpha: 0.05$ ), while Cyanobacteria showed significant differences between these regions ( $t$-test; $p: 0.0001 ; \alpha: 0.05)$. Higher values were observed principally in the estuarine region (Figures 6(a)-(d)).

The calculated AOU showed positive values in both climatic periods. The wet period showed higher values that the dry period (average: +2.7 and $+2.1 \mathrm{ml} \cdot \mathrm{L}^{-1}$, 

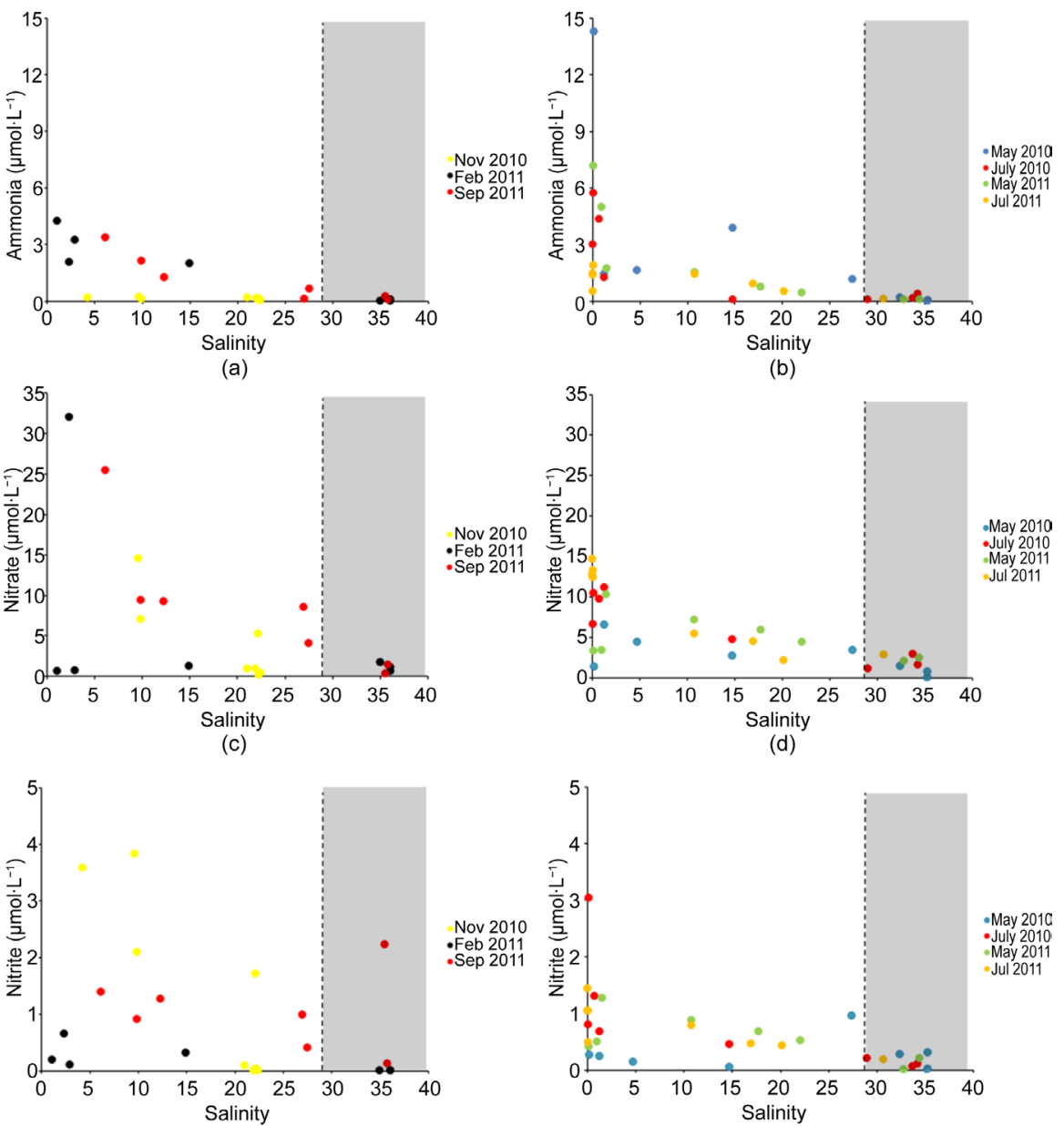

(f)
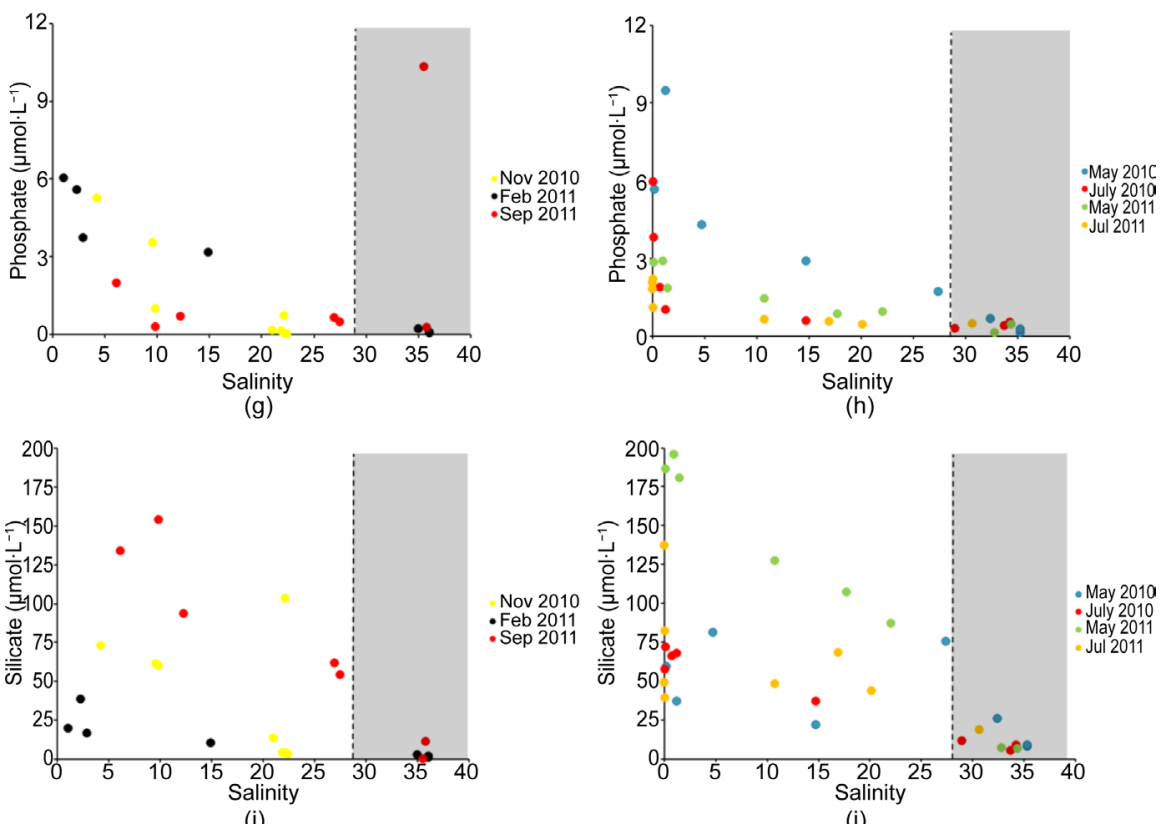

(i)

Figure 5. Concentrations of the dissolved nutrients in the two studied areas: (a)-(b) = ammonia, $(\mathrm{c})-(\mathrm{d})=$ nitrate, $(\mathrm{e})-(\mathrm{f})=$ nitrite, $(\mathrm{g})-(\mathrm{h})=$ phosphate, $(\mathrm{i})-(\mathrm{j})=$ silicate, during dry and rainy periods. Grey area corresponds to plume region. Average and standard deviation for the dry and wet period are also shown. 


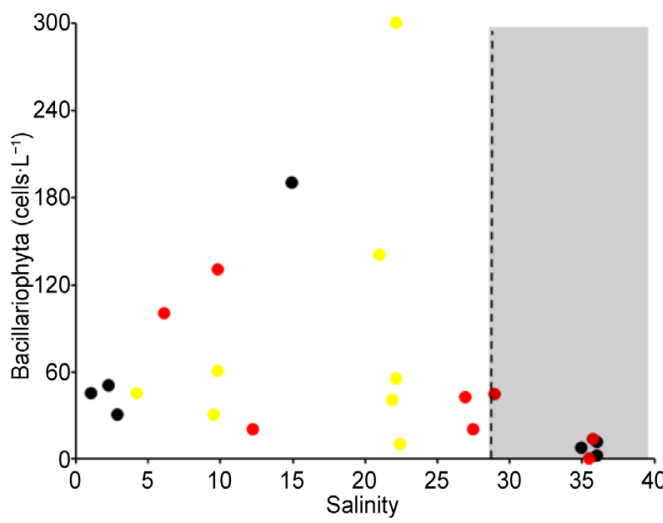

(a)

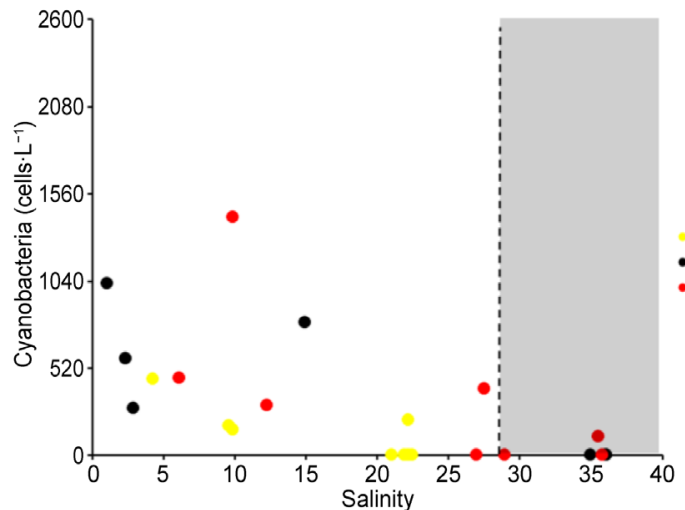

(c)

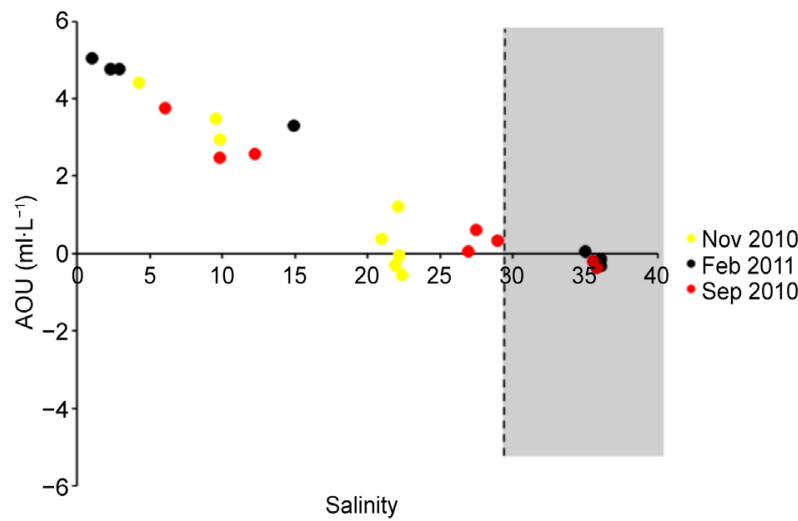

(e)

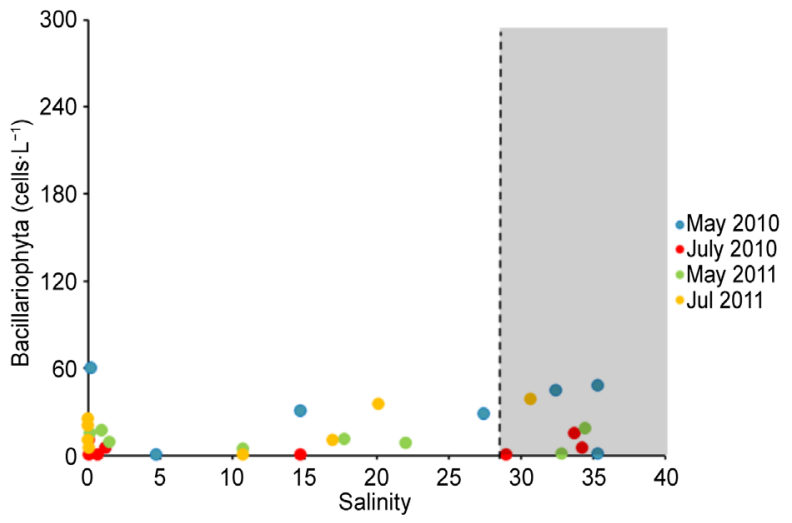

(b)

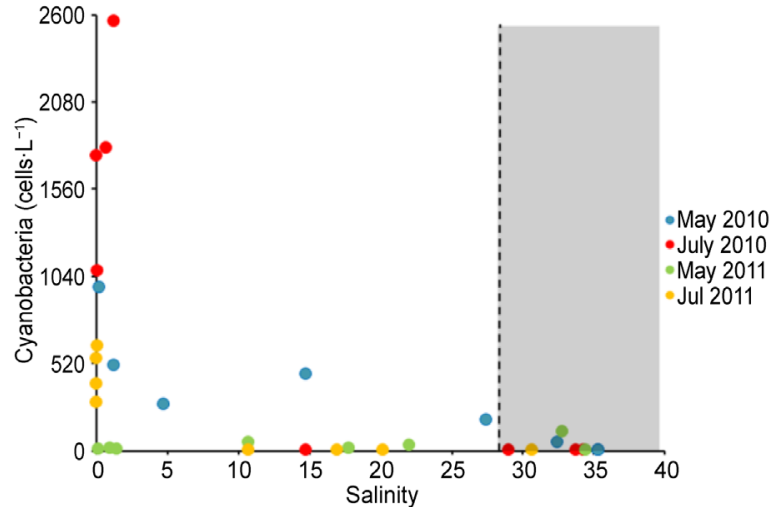

(d)

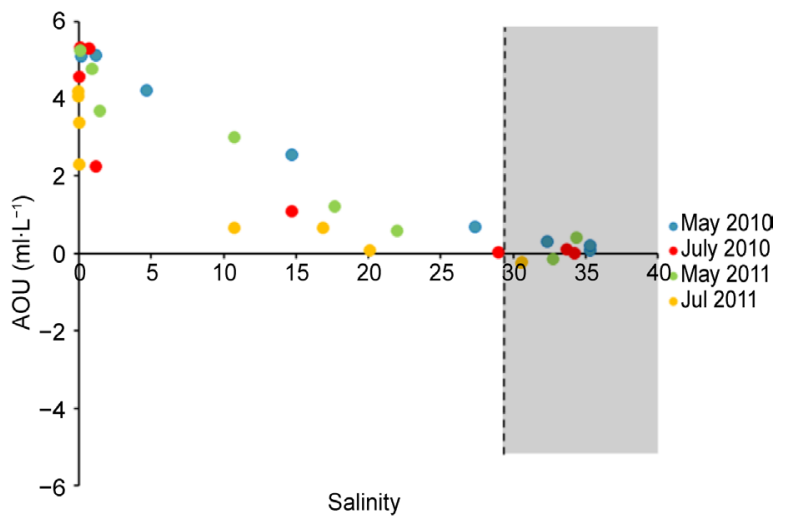

(f)

Figure 6. Bacillariophyta through the salt gradient (a)-(b), Cyanobacteria (c)-(d) and AOU (e)-(f) in the estuary and plume of the Jaboatão River. The dotted line indicates the mean value of salinity in the pen region. Grey area corresponds to plume region. Average and standard deviation for the dry and wet period are also shown.

respectively). Additionally, 2 samples were negatives and were recorded in the dry period, corresponding to $<9 \%$ of the total samples of the period (Figure 6(e), Figure 6(f)).

In the estuary, 38 taxa were identified, and 15 occurred only in that location, with the majority represented by Bacillariophyta (47\%), Cyanobacteria (18\%) and Miozoa (11\%). In the plume region, 65 taxa were recorded, and 39 occurred exclusively in this region, following the general pattern of a majority of Bacil- 
lariophyta (62\%), Miozoa (23\%) and Cyanobacteria (8\%) (Figure 7).

The specific richness showed little difference in the estuary, ranging from seven taxa in July of 2011 to 15 in November of 2010. In the plume region, the difference was quite pronounced, with a minimum of seven taxa in July of 2010 and a maximum of 35 taxa in May of 2010. However, in both sites, no seasonal pattern was evident ( $t$-test; $p$ : $0.0001 ; \alpha$ : 0.05). Only two species were considered to be dominant in the estuary: Microcystis aeruginosa (Kützing) Kützing and Cyclotella meneghiniana Kützing. Microcystis aeruginosa occurred in all seasons and months in the estuary, being dominant in 23 of 28 analysed samples and abundant in the others. Cyclotella meneghiniana was dominant only in station 4 (upstream) in May of 2011. Most taxa were considered rare except Cylindrospermopsis raciborskii (Woloszynska) Seenayya \& Subba Rajuand Oscillatoria tenuis C. Agardh ex Gomont, which were abundant.

The plume region was dominated by Microcystis aeruginosa, Planktothrix agardhii (Gomont) Anagnostidis \& Komárek, Lepocinclis acus (O. F. Müller) Marin \& Melkonian, Protoperidinium bispinum (Schiller) Balech, Coscinodiscus centralis Ehrenberg, Cyclotella meneghiniana and Paralia sulcata (Ehrenberg) Cleve. Climacosphenia moniligera Ehrenberg, Diploneis bombus (Ehrenberg) Ehrenberg, Grammatophora marina (Lyngbye) Kützing, Licmophora abbreviata C. Agardh, Melosira dubia C. G. Kützing, Navicula humerosa Brébisson ex W.
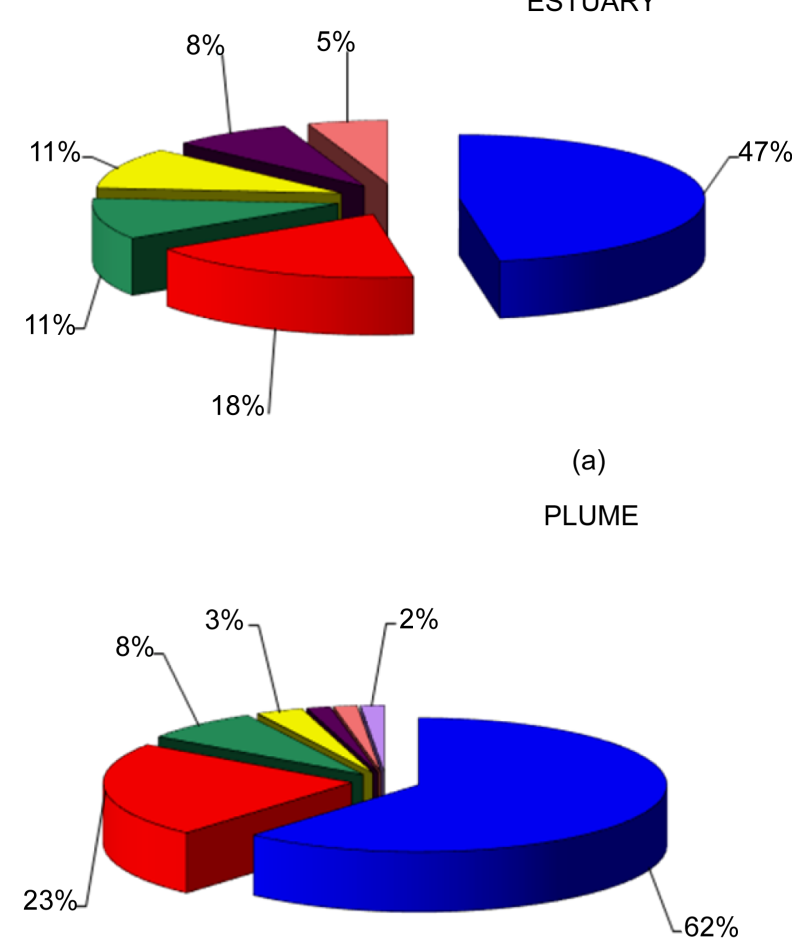

(a)

-BACILLARIOPHYTA -CYANOBACTERIA

-MIOZOA

口EUGLENOPHYTA

-CHLOROPHYA

口CHAROPHYTA

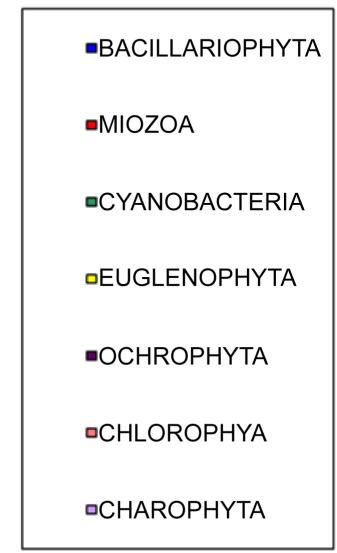

(b)

Figure 7. Percentage of occurrence of phyla in each area studied. 
Smith, Navicula sp., Pleuro/Gyrosigma sp. and Thalassiosira leptopus (Grunow ex Van Heurck) Hasle \& G. Fryxell were abundant (Figure 8).

We identified 38 taxa in the estuary, of which $63 \%$ were sporadic, $29 \%$ were uncommon, $3 \%$ were considered frequent and $5 \%$ were very frequent. The dominant Microcystis aeruginosa and Cyclotella meneghiniana were the very frequent species on the site.

In the plume, no taxon was considered very frequent; $68 \%$ were sporadic, $26 \%$ were uncommon and 6\% were frequent. Among the frequent were Microcystis aeruginosa, Coscinodiscus centralis, Navicula sp. and Paralia sulcata.

In the estuary, the values of specific diversity were between the minimum of 0 bits.Cell ${ }^{-1}$ and the maximum of 1.99 bits.Cell ${ }^{-1}$, with $60 \%$ of the samples presenting low diversity and $40 \%$, very low, while the equitability ranged from 0 to 0.99 , with $90 \%$ of the samples showing high equitability. In the plume region, the diversity was higher, ranging from very low to medium, with 0 bits.Cell ${ }^{-1}$ and 2.98 bits.Cell ${ }^{-1}$, respectively. The equitability presented minimum and maximum values of 0 and 0.99 , with $32 \%$ of the samples presenting medium diversity and $82 \%$ being highly equitable (Figure 9 ).
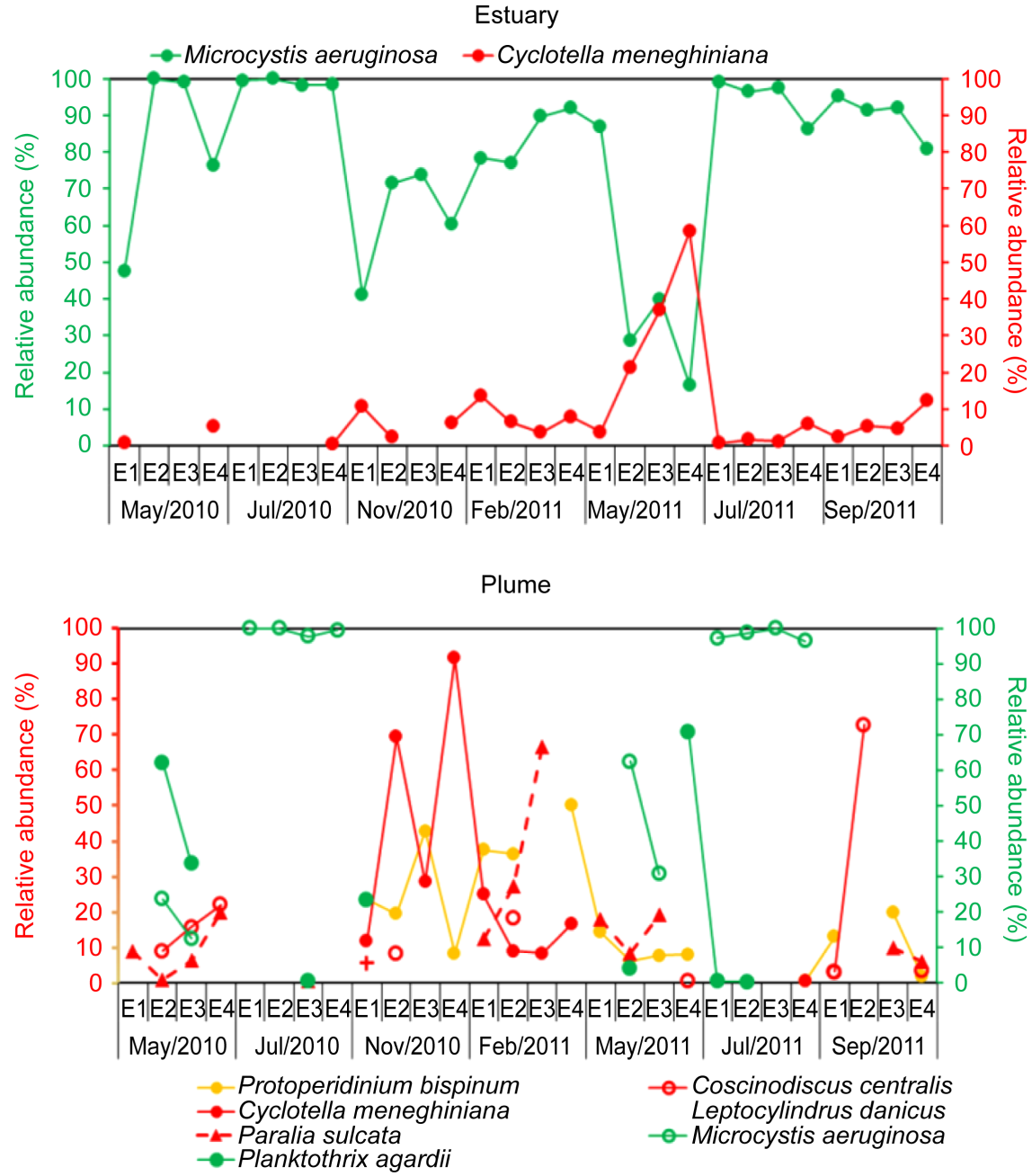

Figure 8. Relative abundance (\%) of the most representative species in the studied areas. 

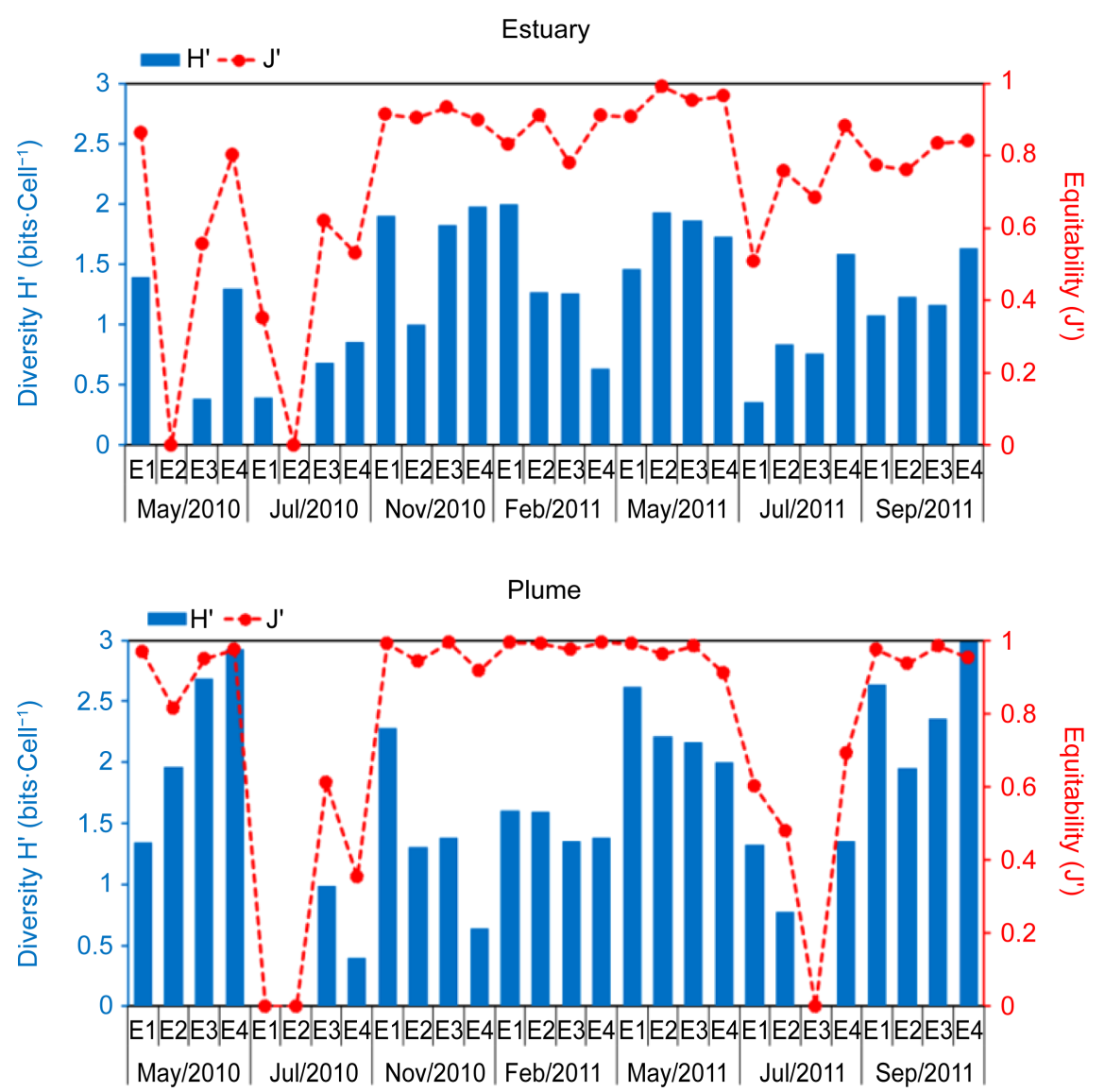

Figure 9. Specific diversity and equitability of the two studied areas.

In cell density, the most representative group in the estuary was the cyanobacteria, with 17548 cell. $\mathrm{L}^{-1} \times 10^{3}$, constituting $92.6 \%$, followed by diatoms, with 1230 cell. $\mathrm{L}^{-1} \times 10^{3}$, constituting $6.5 \%$. The rest of the groups found (Euglenaceae, Dinoflagellates, Chlorophyceae and Carophyceae) totalled $0.9 \%$ in $167 \mathrm{cell} \cdot \mathrm{L}^{-1} \times$ $10^{3}$. In the plumeas well as in the estuary, cyanobacteria constituted $97 \%$ of the cells counted, with $13879 \mathrm{cell} \cdot \mathrm{L}^{-1} \times 10^{3}$, followed by diatoms, with $740 \mathrm{cell} \cdot \mathrm{L}^{-1} \times$ $10^{3}$, representing 2\%; The remaining groups (Euglenophytes, Dinoflagellates, Chlorophyceae, Carophytes and Octylites) were $0.9 \%$, adding $290 \mathrm{cell} \cdot \mathrm{L}^{-1} \times 10^{3}$ (Figure S1; Supplementary material).

In the estuary, the maximum density was 7255 cell. $\mathrm{L}^{-1} \times 10^{3}$ in July of 2010 and a minimum of $126 \mathrm{cell} \cdot \mathrm{L}^{-1} \times 10^{3}$ in May of 2011. In the plume, the density remained below 500 cell. $\mathrm{L}^{-1} \times 10^{3}$ except in the months of July of 2010 and July of 2011, when it reached more than 7000 cell. $\mathrm{L}^{-1} \times 10^{3}$. The minimum recorded in the plume region was $37 \mathrm{cell} \cdot \mathrm{L}^{-1} \times 10^{3}$ and the maximum7618 cell. $\mathrm{L}^{-1} \times 10^{3}$ (Figure S2; Supplementary material).

The cell density in each season showed that the estuary had the highest densities in all stations, but the difference was not significant ( $t$-test; $p: 0.07 ; \alpha: 0.05)$, with densities always above $3000 \mathrm{cell} \cdot \mathrm{L}^{-1} \times 10^{3}$ (Figure S3; Supplementary material). There was also a decreasing downstream-upstream gradient. The species Microcystis aeruginosa was responsible for the predominance of cyanobacteria, 
both in the estuary and in the plume, dominating in $82 \%$ of the estuary and presenting a minimum density of 4 cell. $\mathrm{L}^{-1} \times 10^{3}$ and a maximum of $2560 \mathrm{cell} \cdot \mathrm{L}^{-1} \times$ $10^{3}$. During May of 2011, the density was lower than in the other months studied, with a density of less than 10 cell. $\mathrm{L}^{-1} \times 10^{3}$.

In the plume, $M$. aeruginosa presented a minimum density of $8 \mathrm{cell} \cdot \mathrm{L}^{-1} \times 10^{3}$ and a maximum of $2215 \mathrm{cell} \cdot \mathrm{L}^{-1} \times 10^{3}$. This species showed seasonality in the area, occurring only in the months of the rainy season (May and Julyin both years) at well above its density in July of 2011. It was not possible to show a spatial difference (Figure S4; Supplementary material).

\section{Discussion}

\subsection{Temperature and Salinity}

Studies of phytoplankton and its responses to environmental variables represent important tools for understanding and diagnosing the natural and/or anthropogenic impacts of aquatic ecosystems at the level of primary producers. Natural factors such as rainfall showed a temporal distribution that agreed with historical patterns, but in July 2010 (typical rainy month), the rainfall intensity was lower than the historical average. Thus, no seasonal variations were identified for some physical and chemical factors. Within these factors, the temperature did not show significant differences spatially and temporally. This is a typical pattern for estuaries in northeastern Brazil [17] [18]. This thermal stability is typical of tropical estuarine waters, which can range from $24^{\circ} \mathrm{C}$ to $30^{\circ} \mathrm{C}$, and is related to the salinity gradient that can increase the temperature by up to $4^{\circ} \mathrm{C}$, especially in the less rainy season [43]. Temperature directly influences phytoplankton, promoting an increase in reproduction and growth, especially in temperate regions. This effect is observed less noticeably in tropical waters [44] [45]. The water temperature exerts a direct influence on the physiological processes of the organisms [46], whereas salinity is an important hydrological parameter in the spatial distribution of organisms, presenting gradients that make this factor preponderant in the distribution of aquatic organisms and constitute an ecological barrier for certain species [46].

In the present study, the salinity presented seasonal variation, and rainfall did not seem to influence the values. The plume showed the highest salinity values, as expected, due to the strong marine influence. Spatial variations in the plume, from meso to euhaline, were less evident than in the estuary, where station 1 had the highest salinities andstation 4 (upstream) the lowest, ranging from freshwater to polyhaline.

\section{2. $\mathrm{pH}, \mathrm{DO}$ and Saturation}

In the plume, the $\mathrm{pH}$ remained always alkaline, evidencing the influence of the marine waters in the area. Another author [15] observed similar values in the same area of study. The $\mathrm{pH}$ in the estuary ranged from slightly acidic to alkaline, with the lowest values, generally slightly $<7$, coinciding with the months of more intense precipitation, when they were justified by the influence of freshwater, 
which is more acidic than the marine water. In tropical estuaries, the $\mathrm{pH}$ is generally in the range of alkalinity [17] [18] [47].

Fluctuations of the acid, neutral and alkaline $\mathrm{pH}$ values in the studied environment are related to the degradation processes of organic matter and photosynthetic activities [48] [49], which cause an increase in inorganic dissolved nutrients, mainly ammonia and phosphate, that indicate the presence of domestic effluents rich in organic matter [19]. The environment showed a great variation of $\mathrm{pH}$ due to the low DO values (average: $1.57 \mathrm{ml} \cdot \mathrm{L}^{-1}$ ). According to [50] and [51], the decrease in $\mathrm{pH}$ is related to the increase of dissolved $\mathrm{CO}_{2}$ concentration as a consequence of the increase in organic matter degradation and reduction of photosynthetic activities, which are the main consumers of this gas and directly influence the carbonate system and consequently the $\mathrm{pH}$. The high organic load also reduced light penetration, reducing the photic layer and limiting the density and diversity of phytoplankton despite the high levels of dissolved inorganic nutrients. These factors may alter the concentration and saturation rate of dissolved oxygen, which varied significantly in comparisons of the estuary and the plume, with the latter being much more oxygenated. However, neither site showed any evidence of seasonal variation. Spatially, the estuary became evident, with the oxygen content decreasing as it entered the more internal seasons. In estuarine areas, this variation in dissolved oxygen content is common [15]. Similar values in the Recife basin were recorded by [21] $\left(2.72\right.$ to $\left.6.24 \mathrm{ml} \cdot \mathrm{L}^{-1}\right)$, and [26] recorded values between 1.73 and $7.78 \mathrm{ml} \cdot \mathrm{L}^{-1}$ at the plume of the Capibaribe River (close to our study area).

$\mathrm{DO}$ is one of the most important elements for maintaining the environmental quality of aquatic ecosystems as well as being an essential element for the oxidation, decomposition and cycling of organic matter circulating in ecosystems. In 1978 [52], classified the estuarine ecosystems of northeastern Brazil in terms of water quality based on the oxygen saturation rate, creating categories for supersaturated (>100\%), saturated (75\% to $100 \%$ ), and low saturation (below $75 \%$ ), semi-polluted (25\% to $50 \%)$, and polluted $(<25 \%)$. Except for one point where it was considered saturated, the estuary of the Jaboatão River ranged from polluted to low-saturation zones, evidencing the low quality of its waters. The plume remained saturated to super-saturated. The higher DO contents are related to the more alkaline values of $\mathrm{pH}$ in the plume.

\subsection{Nutrients}

$\mathrm{DO}$ and $\mathrm{pH}$ are altered by temporal and spatial variations of nutrient inputs. The main nutrients are regulated and defined by CONAMA Resolution 357 [42]. According to the Resolution, the waters of the estuary and the plume of the Jaboatão River are considered brackish and salt I class, respectively, with the maximum limits $0.40 \mathrm{mg} \cdot \mathrm{L}^{-1}\left(0.30 \mu \mathrm{mol} \cdot \mathrm{L}^{-1}\right)$ for nitrite, $0.40 \mathrm{mg} \cdot \mathrm{L}^{-1}(1.72$ $\left.\mu \mathrm{mol} \cdot \mathrm{L}^{-1}\right)$ for ammonia and $0.07 \mathrm{mg} \cdot \mathrm{L}^{-1}\left(0.30 \mu \mathrm{mol} \cdot \mathrm{L}^{-1}\right)$ for nitrate. In the estuary, ammonia (average: $2.7 \mu \mathrm{mol} \cdot \mathrm{L}^{-1}$ ), nitrite (average: $1.07 \mu \mathrm{mol} \cdot \mathrm{L}^{-1}$ ) and nitrate (average: $8.86 \mu \mathrm{mol} \cdot \mathrm{L}^{-1}$ ) presented mean values above those specified by the 
CONAMA resolution. In the plume, ammonia (average: $0.26 \mu \mathrm{mol} \cdot \mathrm{L}^{-1}$ ) and nitrite (average: $0.27 \mu \mathrm{mol} \cdot \mathrm{L}^{-1}$ ) presented mean values below the maximum allowed, but nitrate (average: $2.4 \mu \mathrm{mol} \cdot \mathrm{L}^{-1}$ ) remained above the maximum allowed value.

The high values of nitrogen compounds and phosphate (average: $2.97 \mu \mathrm{mol} \cdot \mathrm{L}^{-1}$ ) in the Jaboatão estuary evidenced the high degree and the strong influence of the anthropic action in that environment. The same influence is not observed in the plume, where the nitrogenous compounds as well as phosphate (average: 0.39 $\mu \mathrm{mol} \cdot \mathrm{L}^{-1}$ ) remained within an acceptable limit.

The concentrations of each of the nitrogen compounds are strongly influenced by the dynamic cycle of DO in the medium [19] [53]. In estuarine areas, nutrients generally originate from rivers, usually in an inverse relationship between the concentration of these elements and the salinity [54]. This process was evidenced in the estuary and plume of the Jaboatão River, which presented an inverse relationship between salinity and nutrient concentration. In the estuary, where salinity was lower, nutrient concentrations were higher. In the plume, the reverse process occurred. According to [26], in a study of the Capibaribe River plume, recorded higher values than those found in this study, except for silicate, and a defined seasonal variation, presenting higher concentrations in the rainy season.

The dissolved nutrients presented a spatial variation better evidenced in the estuary than in the plume, but it was not possible to establish a seasonal pattern in both. In estuarine plumes, the contribution is lower because the production of the estuary absorbs a good part of the nutrients, which is minimized in urban areas, where the nutrient supply is high.

\subsection{Phytoplankton Distribution and AOU}

The combined effect of the main physico-chemical factors of the pelagic environment, such as luminous intensity, nutrient concentration, temperature and salinity, determine the geographic distribution, specific composition and variability of the phytoplankton production rates [55]. Knowledge of the taxonomic composition of phytoplankton is fundamental for the study of the spatial and temporal dynamics of the community and for the characterization of functional groups [55].

In the taxonomic composition of the studied environments, the greater representativeness of the diatoms is highlighted, considering the specific richness. In the estuary, after the diatoms, it is possible to show the representativeness of the cyanobacteria, a typical group of freshwater organisms. In the plume, the second-most represented group was the dinoflagellates, a typical marine species. This relationship also occurs in other estuaries, mainly in northeastern Brazil, where the predominance of diatomshas been established [15] [18] [24] [56] [57] [58]. According to [26] also highlight the greater representativeness of diatoms in the plume of the Capibaribe River, followed by the dinoflagellates, which is the same pattern found for the plume of the Jaboatão River.

Diatoms predominate in coastal and shelf regions, gradually decreasing to- 
wards the open ocean, where the contribution of dinoflagellates increases significantly [59], whereas Cyanobacteria can reach high densities in tropical marine waters, possibly constituting the group mainly responsible for primary productivity in cases of a shortage of larger phytoplankton components [60].

The cell density of the Cyanobacteria Microcystis aeruginosa predominated in practically all the estuarine stations, with blooms in July of 2010 and September of 2011. In the plume region, however, its occurrence was punctual, with blooms in July of 2010 and 2011.

Previous research on the estuarine ecosystem of the Jaboatão River by [13] [15] [28] considers the diatoms Bellerochea malleus, Coscinodiscus centralis and Cyclotella meneghiniana to be dominant and very frequent as the key species for that ecosystem. In the present study, Microcystis aeruginosa is considered the key species in the studied area due to its high density, dominance and frequency of occurrence at all estuarine stations.

Previous data analysed by [14] referred to a specific diversity ranging from medium to high. A recent study by [13] and [16] revealed a marked reduction of this diversity, and in the present study, the diversity reached a value of zero, a fact that is supported by the flowering of Microcystis aeruginosa, demonstrating a highly compromised ecosystem.

Cyanobacteria are especially abundant in waters with high temperatures that arerich in nutrientsor in polluted waters with little oxygen where they can form a dense scum that can colour the water, forming blooms. Blooms of M. aeruginosa produce toxins and have been implicated in the mass mortality of aquatic animals and the destabilization of food webs [61] [62].

Additionally, the positive values shown by calculated AOU indicate higher rates of respiration (production-respiration), where $\mathrm{DO}$ is consumed and $\mathrm{CO}_{2}$ released in the water column.

According to [63] the registration of a significant density of phytoplanktonic organisms against low species richness suggests that a habitat has received a polluting load, allowing a favourable environment for organisms that are tolerant of this condition. This was evidenced both in the plume and in the estuary, where the occurrence of other species was limited in the stations dominated by this Cyanobacteria group.

\subsection{Principal Component Analysis (PCA)}

We statistically analysed the physical, chemical, biological and rain data through a Principal Component Analysis (PCA) to obtain spatial and temporal correlations and correlations between the parameters analysed in this study (Figure 10(a), Figure 10(b)). According to the PCA, the first 4factors explained $72.70 \%$ of the environmental variations that were correlated with the species considered to be very frequent (Table S2; Supplementary material). In Figure 10(a), component 1 explained $40.0 \%$ of the environmental variations analysed and showed a direct correlation between water transparency (Secchi), salinity, $\mathrm{pH}$ and DO. These parameters had an inverse correlation with nutrients (ammonia- $\mathrm{NH}_{4}^{+}$, 

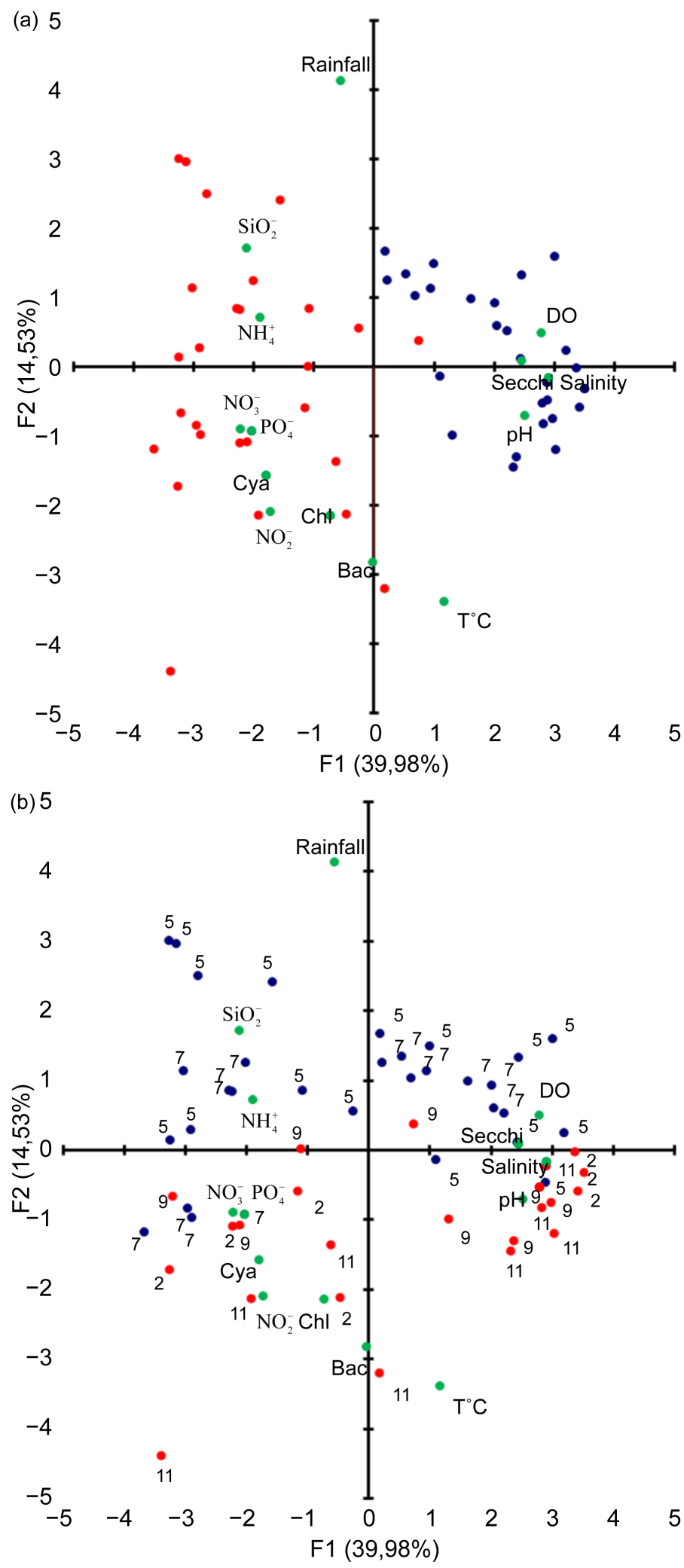

Figure 10. Spatial PCA of the chemical, physical and biological parameters. Green circles indicate the parameters; Red circles indicate the estuarine region; Blue circles indicate the region of the plume (a). Temporal PCA of chemical, physical and biological parameters. Green circles indicate the parameters; Red circles indicate the dry period; Blue circles indicate the rainy period (b). 
nitrate $-\mathrm{NO}_{3}^{-}$, nitrite $-\mathrm{NO}_{2}^{-}$, silicate $-\mathrm{SiO}_{2}^{-}$) and the Cyanophytes group.

Component 2 explained $14.53 \%$ of the variability and showed an inverse correlation between temperature $\left(\mathrm{T}^{\circ} \mathrm{C}\right)$ and rainfall. Biological parameters were located in component 4 and showed an inverse correlation between Bacillariophyta (Bac) and Cyanobacteria (Cya).

We identified a clear spatial division between the estuary and the plume. A group of parameters was associated with the estuarine region (nutrients, Cyanobacteria, Bacillariophyta and Chlorophyta), while another group was associated with the plume region (DO, Secchi, salinity and $\mathrm{pH}$ ).

A second PCA was performed to include temporal variability (months) in the biplot. We observed that salinity, $\mathrm{pH}$ and water transparency (Secchi) are associated with dry-season months (February and November), whereas nutrients are associated with the winter months. The biological groups of component 4 appear to be associated with the dry period (November). Temperature and rainfall did not show a defined pattern within the biplot (Figure 10(b)). Additionally, we included a time series of 12 years (1999 to 2011) based on similar studies carried out in this aquatic system. We used AOU calculated from the values of salinity, oxygen and temperature to compare the estuarine system with the fluvial system.

\subsection{Trend of AOU and Change in the Phytoplankton Species}

Data obtained from the CPRH database (1999 to 2011) [63] [64], were used to calculate AOU in the Jaboatão River. We used data from the fluvial station with greater geographic and data coverage. The dataset in the estuarine region was limited to 28 data (months). The results of this exercise can be seen in Figure 11(a), Figure 11(b). Figure 11(a) shows a positive AOU series with the exception of 2 months (negative values). The mean value in the river series was higher than that in the estuarine series. The calculated trend of AOU for the river was negative, whereas the estuarine series had a slight positive trend. In the estuarine region, the main biological components changed through 1999-2011 period. Bacillariophyta had been the dominant species in previous studies, while in our study between 2010 and 2011, the Cyanophyta group was dominant.

\section{Conclusion}

We can conclude that the Jaboatão estuary is strongly impacted because of the lower values of salinity and dissolved oxygen and the high concentration of nutrients, mainly the nitrogenous and phosphate components indicative of high pollutant loads. Additionally, the cyanobacteria Microcystis aeruginosa, an opportunistic and potentially toxic species, constitutes the dominant species responsible for the low diversity of species in recent years, as demonstrated by the observations in the temporal series. The plume, with well-oxygenated waters, high salinity and low concentration of nutrients, indicates the influence of the marine flow in the area, allowing the dominance of other species and contributing to the increase of local diversity. 

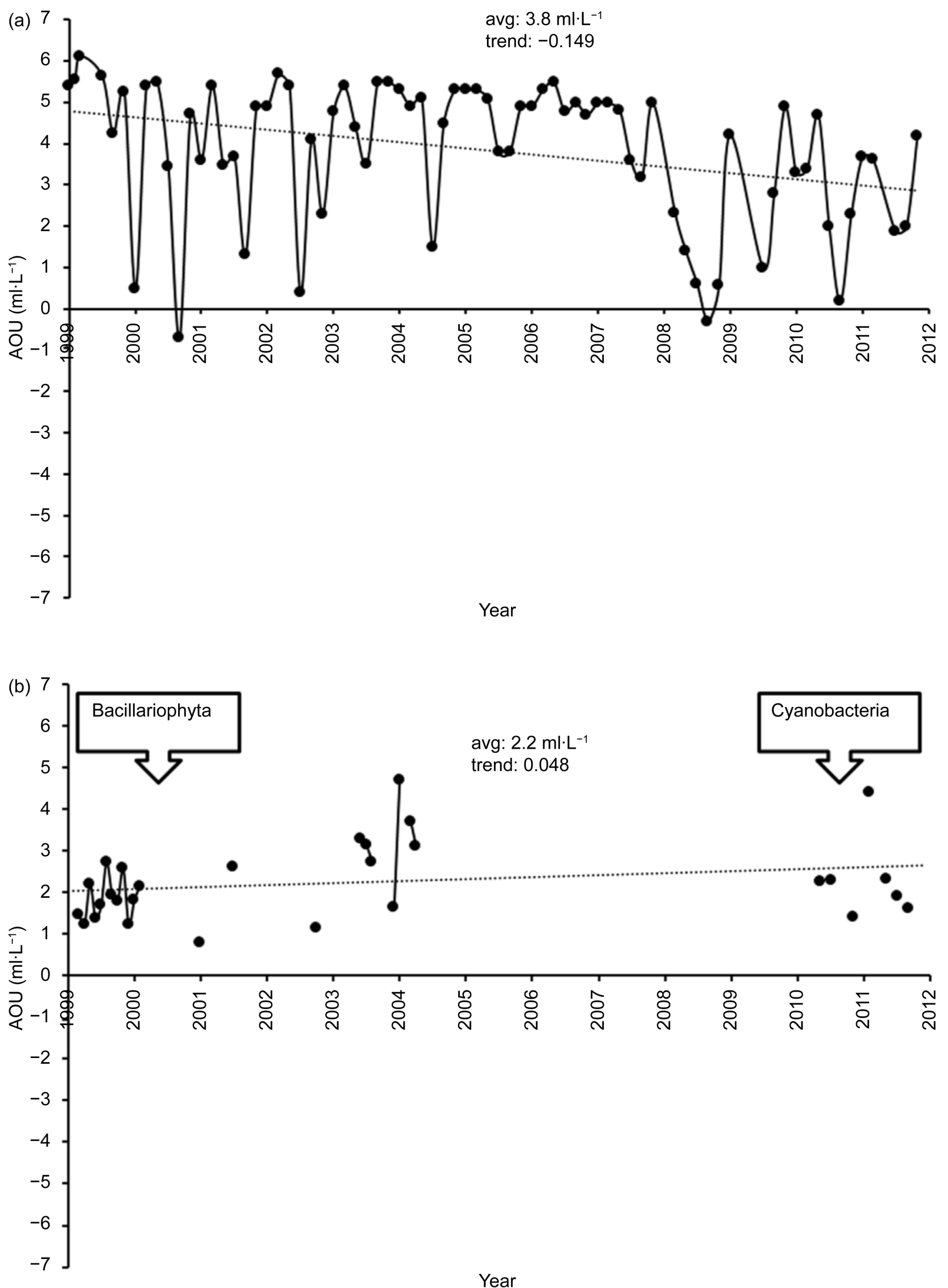

Figure 11. Time series (1999-2011) of the AOU calculated in the fluvial region (a) and in the estuarine region (b). The dotted line indicates the trend of the series (b). 


\section{Acknowledgements}

The authors thank the National Council for Scientific and Technological Development (CNPq) for financial support to the project (Process No. 558106/20099). C. Noriega acknowledges Coordination for the Improvement of Higher Levelor Education-Personnel-CAPES (Process No. 1975/2014-DICAM. A. Xavier acknowledges the information provided by the State Environmental Agency (CPRH).

\section{References}

[1] Meire, P., Ysebaert, T., Van Damme, S., Van Den Bergh, E., Maris, T. and Struyf, E. (2005) The Scheldt Estuary: A Description of a Changing Ecosystem. Hydrobiologia, 540, 1-11. https://doi.org/10.1007/s10750-005-0896-8

[2] Miranda, L.B., Castro, B.M. and Kjerfve, B. (2002) Princípios de oceanografia física de estuários. EDUSP, São Paulo.

[3] Marques, W.C. (2006) A dinâmica da pluma costeira da Lagoa dos Patos, Brasil. Ph.D. Thesis, Federal University of Rio Grande, Rio Grande.

[4] Graham, J.E., Barret, N.S., Graddon, D.J. and Last, P.R. (2000) The Conservation Significance of Estuaries: A Classification of Tasmanian Estuaries Using Ecological, Physical and Demographic Attributes as a Case Study. Biological Conservation, 92, 383-397. https://doi.org/10.1016/S0006-3207(99)00111-1

[5] Livingston, R.J. (2001) Eutrophication Processes in Coastal Systems: Origin and Succession of Plankton Blooms and Effects on Secondary Production in Gulf Coast Estuaries Center for Aquatic Research and Resource Management. CRC Press, Florida.

[6] Ortega, J.L.G. (2000) Algas. In: Espino, G.L., Pulido, S.H. and Perez, J.L.C., Eds., Organismos indicadores de la calidad del agua y de la contaminación (Bioindicadores), Playa y Valdés S.A., México city, 109-193.

[7] UNESCO, United Nations Educational Scientific and Culture Organization (1981) Background Papers and Supporting Data on the Practical Salinity Scale. Technical Papers Marine Sc., Vol. 37.

[8] Sousa, E.B., Costa, V.B., Pereira, L.C.C. and Costa, R.M. (2009) Variação temporal do fitoplâncton e dos parâmetros hidrológicos da zona de arrebentação da Ilha Canela (Bragança, Pará, Brasil). Acta Botânica Brasílica, 23, 1084-1095. https://doi.org/10.1590/S0102-33062009000400018

[9] Eskinazi, E. and Satô, S. (1966) Contribuição ao estudo das diatomáceas da praia de Piedade. Trabalhos Oceanográficos da Universidade Federal de Pernambuco, 5/6: 73-114.

[10] Flores Montes, M.J., Macêdo, S.J., Koening, M.L. and Correia, I.L. (1998) Variação nictemeral do fitoplâncton e elementos nutrientes do Canal de Santa Cruz, Itamaracá-PE-Brasil. Trabalhos Oceanográficos da Universidade Federal de Pernambuco, 26, 13-26.

[11] Koening, M.L., Eskinazi-Leça, E. and Neumann-Leitao, S. (2002) Impactos da construção do Porto de Suape sobre a comunidade fitoplanctônica no estuário do rio Ipojuca (Pernambuco-Brasil). Acta Botânica Brasílica, 16, 407-422. https://doi.org/10.1590/S0102-33062002000400004

[12] Feitosa, F.A.N., Silva-Cunha, M.G.G. and Branco, E.S. (2002) Composição florística do microfitoplâncton no sistema estuarino de Barra das Jangadas (Jabotão dos Guararapes-Pernambuco-Brasil). Arquivos de Ciências do Mar, 37, 63-76. 
[13] Lacerda, S.R., Koening, M.L., Neumann-Leitao, S. and Flores-Montes, M. (2004) Phytoplankton Nyctemeral Variation at a Tropical River Estuary (Itamaracá-Pernambuco-Brazil). Brazilian Journal of Biology, 64, 81-94. https://doi.org/10.1590/S1519-69842004000100010

[14] Branco, E., Feitosa, F.A.N., Silva Cunha, G., Neuman Leitão, S. and Vitorio, U. (2006) Variação sazonal das algas planctônicas correlacionadas com parâmetros ambientais no estuário de Barra das Jangadas (Jaboatão dos Guararapes-Brasil). Boletim Técnico Científico da CEPENE, 14, 17-23.

[15] Branco, E. (2007) Influência das variáveis ambientais na estrutura da comunidade fitoplanctônica do sistema estuarino de Barra de Jangadas (Pernambuco-Brasil). Ph.D. Thesis, Federal University of Pernambuco, Recife.

[16] Branco, E.S. (2008) Influência das Variáveis Ambientais na Comunidade Fitoplanctônica Estuarina. Editora Universitária, Recife.

[17] Grego, C.K.S., Feitosa, F.A.N., Honorato da Silva, M., Silva-Cunha, M.G.G. and Nascimento Filho, G.A. (2009) Fitoplâncton do ecossistema estuarino do rio Ariquindá (Tamandaré, Pernambuco, Brasil): Variáveis ambientais, biomassa e produtividade primária. Atlântica, 31, 183-198. https://doi.org/10.5088/atl.2009.31.2.183

[18] Honorato da Silva, M., Silva-Cunha, M.G.G., Passavante, J.Z.O., Grego, C.K.S. and Muniz, K. (2009) Estrutura sazonal e espacial do microfitoplâncton no estuário tropical do rio Formoso, PE, Brasil. Acta Botânica Brasílica, 23, 355-368. https://doi.org/10.1590/s0102-33062009000200007

[19] Noriega, C. and Araujo, M. (2009) Nitrogen and Phosphorus Loading in Coastal Watersheds in Northeastern Brazil. Journal Coastal Research, 56, 871-875.

[20] Rodrigues, E.I. and Cutrim, M.V.J. (2010) Relações entre as variáveis físicas, químicas e fitoplanctônicas de três áreas estuarinas da costa Norte do Brasil-São José de Ribamar, Cedral e Cajapió, Estado do Maranhão. Arquivos de Ciências do Mar. Fortaleza, 43, 45-54.

[21] Santiago, M.F., Silva-Cunha, M.G.G., Neumann-Leitao, S., Costa, K.M., Borges, G.C.P., Porto Neto, F.F. and Nunes, F.S. (2010) Phytoplankton Dynamics in a Highly Eutrophic Estuary in Tropical, Brazil. Brazilian Journal of Oceanography, 58, 189-205. https://doi.org/10.1590/S1679-87592010000300002

[22] Aquino, E.P., Borges, G.C.P., Honorato Da Silva, M., Passavante, J.Z.O. and SilvaCunha, M.G.G. (2014) Microphytoplankton Community and Environmental Variables in an Urban Eutrophic Estuary (Capibaribe River, Northeast, Brazil). PanAmerican Journal Aquatic Science, 9, 267-277.

[23] Eskinazi-Leça, E., Silva-Cunha, M.G.G., Koening, M.L., Macêdo, S.J. and Costa, K.M.P. (1997) Variação espacial e temporal do fitoplâncton na Plataforma Continental de Pernambuco-Brasil. Trabalhos Oceanográficos da Universidade Federal de Pernambuco, 25, 1-16.

[24] Eskinazi-Leça, E., Koening, M.L. and Silva-Cunha, M.G.G. (2004) Estrutura e dinâmica da comunidade fitoplanctônica. In: Eskinazi-Leça, S., Neumann-Leitao, S. and Costa, M.F., Eds., Oceanografia: Um Cenário Tropical, Bagaço, Recife, 353-373.

[25] Koening, M.L., Wanderley, B.E. and Macêdo, S.J. (2009) Microphytoplankton Structure from the Neritic and Oceanic Regions of Pernambuco State-Brazil. Brazilian Journal of Biology, 69, 1037-1046. https://doi.org/10.1590/S1519-69842009000500007

[26] Melo, M.A.F., Koening, M.L., Souto, J.R.F., Travassos, R.K. and Silva, A.C. (2014) Microfitoplâncton de águas costeiras adjacentes ao porto do recife (PE-Brasil). Tropical Oceanography, 42, 80-94.

[27] Araujo, M., Medeiros, C. and Ribeiro, C. (1999) Energy Balance and Time-Scales of 
Mixing and Stratification in the Jaboatão Estuary, NE-Brazil. Brazilian Journal of Oceanography, 47, 145-154. https://doi.org/10.1590/s1413-77391999000200004

[28] Branco, E., Feitosa, F.A.N. and Flores Montes, M. (2002) Variação sazonal e espacial da biomassa fitoplanctônica relacionada com parâmetros hidrológicos no estuário de Barra das Jangadas (Jaboatão dos Guararapes-Pernambuco-Brasil). Tropical Oceanography, 39, 79-96.

[29] Noriega, C. and Araujo, M. (2011) Nutrient Budgets (C, N and P) and Trophic Dynamics of a Brazilian Tropical Estuary: Barra das Jangadas. Anais Academia da Brasileira de Ciências, 83, 441-456.

https://doi.org/10.1590/S0001-37652011000200007

[30] IBGE-Brazilian Institute of Geography and Statistics. Census 2010.

http://www.ibge.gov.br/home/

[31] CPRH-State Agency for Environment and Water Resources (2003) Report on the Monitoring of Water Quality in the Watersheds of the State of Pernambuco in 2010, Recife. http://www.cprh.pe.gov.br/

[32] SECTMA-Secretary of Science, Technology and Environment (1999) Plano estadual de recursos hídricos, PERHPE. http://www.inmet.gov.pe.br

[33] Souza, A. and Tundisi, J. (2003) Water Quality in Watershed of the Jaboatão River (Pernambuco, Brazil): A Case Study. Brazilian Archives of Biology and Technology, 46, 711-721. https://doi.org/10.1590/S1516-89132003000400026

[34] McLusky, D.S. (1993) Marine and Estuarine Gradients. Netherlands Journal of Aquatic Ecology, 27, 489-493. https://doi.org/10.1007/BF02334809

[35] Strickland, J.D.H. and Parsons, T.R. (1972) A Pratical Handbook of Seawater Analysis. 2nd Edition, Fisheries Research Board of Canada Bulletim, Ottawa, 1-205.

[36] Grasshoff, K., Ehrardt, M. and Kremling, K. (1983) Methods of Seawater Analysis. 2nd Edition, VelagChemie, New York.

[37] UNESCO-United Nations Educational Scientific and Culture Organization (1986) International Oceanographic Tables. Vol. 4, NIO-UNESCO, Paris, 193 p.

[38] Garcia, H. and Gordon, L. (1992) Oxygen Solubility in Seawater: Better Fitting Equations. Limnology and Oceanography, 37, 1307-1312.

https://doi.org/10.4319/lo.1992.37.6.1307

[39] Hasle, G.R. (1978) The Inverted-Microscope Methods. In: Sournia, A., Ed., Phytoplankton Manual, UNESCO, Paris, 88-96.

[40] Edler, L. (1979) Recommendations of Methods of Marine Biological Studies in the Baltic Sea: Phytoplankton and Chlorophyll. The Baltic Marine Biologists, Lund, 138.

[41] Ferrario, M., Sars, E. and Sala, S. (1995) Metodologia Básica Para el Estúdio de Fitoplancton com Especial Referencia a las Diatomáceas. In: Alvear, K., Ferrario, M., Oliveira, F.E.C. and Sars, E., Eds., Manual de Métodos Ficológicos, University of Concepción, Concepcion, 1-25.

[42] National Council of the Environment (2005) Resolution 357-Classification of Water Bodies and Environmental Guidelines. http://www.mma.gov.br/port/conama

[43] Monteiro, S.M., El-Robrini, M. and Alves, I.C.C. (2015) Dinâmica Sazonal de Nutrientes em Estuário Amazônico. Mercator, 14, 151-162.

https://doi.org/10.4215/RM2015.1401.0010

[44] Eskinazi-Leça, E., Barros-França, L.M. and Macêdo, S.J. (1984) Estudo Ecológico da Área de Itamaracá (Pernambuco-Brasil), "Standing Stock" do Fitoplâncton do Estuário do Rio Botafogo, Durante Janeiro a Dezembro/75. Trabalhos Oceanográficos da Universidade Federal de Pernambuco, 18, 153-191. 
[45] Koening, M.L. and Macêdo, S.J. (1999) Hydrology and Phytoplankton Community Structure at Itamaracá-Pernambuco (Northeast Brazil). Brazilian Archives of Biology and Technology, 42, 381-392. https://doi.org/10.1590/s1516-89131999000400002

[46] Frazão, E. and Vital, H. (2004) Hydrodynamic and Morpho-Sedimentary Characterization of the Potengi Estuary and Adjacent Areas (NE Brazil): Subsidies towards Oil Spilling Environmental Control. Journal of Coastal Research, SI39, 1446-1449.

[47] Paiva, R.S., Eskinazi-Leça, E., Silva-Cunha, M.G.G. and Melo, N.C. (2006) Considerações Ecológicas Sobre o Fitoplâncton da Baía do Guarajá e Foz do Rio Guamá (Pará, Brasil). Boletim do Museu Paraense Emílio Goeldi, 1, 133-146.

[48] Bambi, P., Dias, C.A.A. and Pinto-Silva, V. (2008) Produção Primária do Fitoplâncton. UNI Ciencias, 12, 47-64.

[49] Travassos, R.K., Flores-Montes, M., Costa, B.V.M. and Silva, J.J.M. (2016) The Influence of Urban Effluents on the Elemental C/N Ratio in a Tropical Coastal Area of Northeastern Brazil. Journal of Coastal Research, SI75, 101-103.

[50] Noriega, C., Araujo, M., Lefevre, N., Flores-Montes, M., Gaspar, F. and Veleda, D. (2015) Spatial and Temporal Variability of $\mathrm{CO}_{2}$ Fluxes in Tropical Estuarine Systems near Areas of High Population Density in Brazil. Regional Environmental Change, 15, 619-630. https://doi.org/10.1007/s10113-014-0671-3

[51] Gaspar, F. (2015) Distribuição da Alcalinidade Total, Pressão Parcial do $\mathrm{CO}_{2}$ e Fluxos de $\mathrm{CO}_{2}$ na Interface Água-Ar no Ecossistema Costeiro do Estado de Pernambuco. Ph.D. Thesis, Federal University of Pernambuco, Recife.

[52] Macêdo, S. and Costa, K.M.P. (1978) Estudo Ecológico da Região de Itamaracá Pernambuco-Brasil, Condições Hidrológicas do Estuário do Rio Botafogo. Ciência e Cultura, 30, 346-368.

[53] Day, J.W., Hall, C.A.S., Kemp, W.M. and Yáñez-Arancibia, A. (1989) Estuarine Ecology. John Wiley and Sons, New York.

[54] Noriega, C.D., Costa, K.M.P., Araujo, M., Travassos, R.K. and Neumann-Leitao, S. (2005) Fluxos de Nutrientes Inorgânicos Dissolvidos em um Estuário TropicalBarra das Jangadas, PE, Brasil. Tropical Oceanography, 33, 129-139.

[55] Gameiro, C., Cartaxana, P. and Brotas, V. (2007) Environmental Drivers of Phytoplankton Distribution and Composition in Tagus Estuary, Portugal. Estuarine, Coastal and Shelf Scieence, 75, 21-34. https://doi.org/10.1016/j.ecss.2007.05.014

[56] Passavante, J.Z.O. (1979) Contribuição ao Estudo dos Dinoflagelados da Plataforma Continental de Pernambuco-Brasil Trabalhos. Oceanográficos da Universidade $\mathrm{Fe}$ deral de Pernambuco, 14, 31-54.

[57] Trigueros, J.M. and Orive, E. (2001) Seasonal Variation of Diatoms and Dinoflagellates in a Shallow, Temperate Estuary, with Enphasis on Neritic Assemblages. Hydrobiologia, 444, 199-133.

[58] Rosevel, S.M., Silva-Cunha, M.G.G., Feitosa, F.A.N. and Muniz, K. (2005) Estrutura da Comunidade Fitoplanctônica na Baía de Tamandaré (Pernambuco, Nordeste do Brasil). Tropical Oceanography, 33, 157-175.

[59] Fernandez, L.F. and Brandini, F.P. (2004) Diatom Associations in Shelf Waters off Parana State, Southern Brazil: Annual Variation in Relation to Environmental Factors. Brazilian Journal of Oceanography, 52, 19-34. https://doi.org/10.1590/S1679-87592004000100003

[60] Lalli, C.M. and Parsons, T.R. (1997) Biological Oceanography: An Introduction. 2nd Edition, Butterworth Heinemann, Oxford.

[61] Oberholster, P.J., Botha, A.M. and Grobbelaar, R. (2004) Microcystis Aeruginosa: 
Source of Toxic Microcystins in Drinking Water. African Journal of Biotechnology, 3, 159-168. https://doi.org/10.5897/AJB2004.000-2029

[62] Black, K. (2011) Growth and Toxin Production by Microcystis Aeruginosa PCC 7806 (Kutzing) Lemmerman at Elevated Salt Concentrations. Journal of Environmental and Protection, 2, 669-674. https://doi.org/10.4236/jep.2011.26077

[63] State Agency for Environment and Water Resources (2010) Report on the Monitoring of Water Quality in the Watersheds of the State of Pernambuco in 2010. State Agency for Environment and Water Resources, Recife. http://www.cprh.pe.gov.br/

[64] State Agency for Environment and Water Resources. (2013) Report on the Monitoring of Water Quality in the Watersheds of the State of Pernambuco in 2013. State Agency for Environment and Water Resources, Recife. http://www.cprh.pe.gov.br/ 


\section{Supplementary Material}

\section{Phytoplankton}

The samples for the phytoplankton study were collected with Ninskin oceanographic bottles and later fixed with lugol solution. The analyzes were performed according to the sedimentation method of Utermöhl [1] [2] [3], and counts performed under ZEISS Axiovert inverted microscope. Samples were homogenized and placed in $10 \mathrm{~mL}$ chambers, stained with Bengal Rose and placed to sediment for 24 hours. The counts were performed with $400 \mathrm{X}$, using the technique of transection. The standardized counting of two transects was used in each chamber. In cases of sample poverty, counts covered the entire chamber. The values of phytoplankton density were expressed in cells per liter (cells $\left.\cdot \mathrm{L}^{-1}\right)$.

Taxonomic identification was done by consulting specialized literature. For the framing of taxa and checking of all scientific names, the international database was used Algaebase [4]; http://www.algaebase.org.).

The relative abundance of the taxa was determined by considering the categories: dominant, species whose numerical occurrences were greater than $50 \%$ of the total number of individuals in the sample; Abundant, species whose occurrence exceeds the average number of individuals in the sample; Rare, species whose occurrences are less than the average number of individuals in the sample. In order to calculate the frequency of occurrence, the number of samples, in which each taxon occurred, and the total number of samples were analyzed, using the formula described by [5], considering: Very common $(\geq 70 \%)$, common $(70 \% \mid-40 \%)$, infrequent $(40 \% \mid-10 \%)$ or sporadic $(<10 \%)$.

For the calculations of specific diversity, the Shannon index [6] was used; the values obtained were classified by Valentin classification [7], being considered high when the results were $\geq 3.0$ bits.cel $^{-1}$; average, with results between 2 and 3 bits.cel ${ }^{-1}$; low, between 1 and 2 bits.cel ${ }^{-1}$; and very low, with result $\leq 1$ bit.cel ${ }^{-1}$; The equitability $\left(J=H^{\prime} \log S\right)$ was calculated according to [8]. In order to calculate this index, the Plymouth Routines in Multivariate Ecological Research, PRIMER $6.0^{\circ}$ statistical software program was used.

\section{References}

[1] Hasle, G.R. (1978) The Inverted-Microscope Methods. In: Sournia, A., Ed., Phytoplankton Manual, United Nations Educational, Scientific, and Cultural Organization, Paris, 88-96.

[2] Edler, L. (1979) Recommendations of Methods of Marine Biological Studies in the Baltic Sea: Phytoplankton and Chlorophyll. The Baltic Marine Biologists, 5, 1-38.

[3] Ferrario, M., Sars, E. and Sala, S. (1995) Metodologia Básica Para el Estúdio de Fitoplancton com Especial Referencia a las Diatomáceas. In: Alvear, K., Ferrario, M., Oliveira, F.E.C. and Sars, E., Eds., Manual de Métodos Ficológicos, University of Concepción, Concepcion, 1-25.

[4] Guiry, M.D. and Guiry, G.M. (2015) AlgaBase. Worldwide Eletronic Publication, National University of Ireland, Galway. 
[5] Mateucci, D. and Colma, A. (1982) La Metodologia Para el Estudo de Iavegetácion. Coleccion de Monografias Cientificas. General Secretariat of the Organization of American States, Washington DC.

[6] Shannon, C.E. (1948) A Mathematical Theory of Communication. Bulletin System Technology Journal, 27, 379-423.

https://doi.org/10.1002/j.1538-7305.1948.tb01338.x

[7] Valentin, J.L. (2000) Ecologia Numérica: Uma Introdução à Análise Multivariada de Dados Ecológicos. Interciência, Rio de Janeiro.

[8] Pielou, E.C. (1977) Mathematical Ecology. Wiley, New York.

Table S1. List of taxa identified in the estuary and plume of the Jaboatão River, Pernambuco, Brazil.

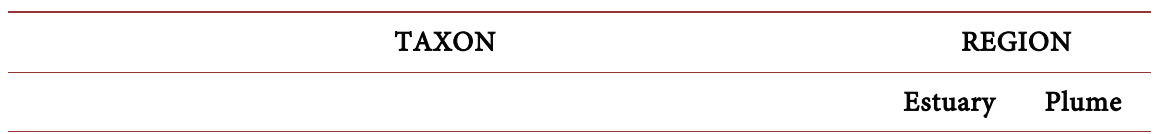

CYANOBACTERIA

CYANOPHYCEAE

NOSTOCALES

APHANIZOMENACEAE

Dolichospermum spiroides (Klebhan) Wacklin, L. Hoffmann \& Komárek $\quad \mathrm{X}$

Cylindrospermopsis raciborskii (Woloszynska) Seenayya \& SubbaRaju $\quad \mathrm{X}$

CHROOCOCCALES

CHROOCOCCACEAE

Chroococcus sp. Nägeli

MICROSCYSTACEAE

Microcystis aeruginosa (Kützing) Kützing

OSCILLATORIALES

OSCILLATORIACEAE

Oscillatoria limosa C. Agardhex Gomont

Oscillatoria tenuis C. Agardhex Gomont

$\mathrm{X}$

Phormidium sp. Kützing ex Gomont

$\mathrm{X}$

$\mathrm{X}$

MICROCOLEACEAE

Planktothrix agardhii (Gomont) Anagnostidis \& Komárek

$\mathrm{X}$

$\mathrm{X}$

Trichodesmium thiebautii Gomont ex Gomont

EUGLENOPHYTA

EUGLENOPHYCEAE

EUGLENALES

PHACACEAE

Lepocinclis acus (O. F. Müller) Marin \& Melkonian

$\mathrm{X}$

$\mathrm{X}$

Phacus sp. Dujardin

$\mathrm{X}$

EUGLENACEAE 


\section{Continued}

Euglena sp. Ehrenberg

Trachelomonas sp. Ehrenberg

$\mathrm{X}$

MIOZOA

DINOPHYCEAE

DINOPHYSIALES

DINOPHYSIACEAE

Dinophysis dubia Balech

GONYAULACALES

GONYAULACACEAE

Gonyaulax polygramma Stein

CERATIACEAE

Tripos furca (Ehrenberg) F. Gómez

Tripos teres (Kofoid) F. Gómez

PYROPHACACEAE

Pyrophacus horologicum Stein

GYMNODINIALES

GYMNODINIACEAE

Gymnodinium sp. F. Stein

PERIDINIALES

OXYTOXACEAE

Oxytoxum scolopax Stein

PROTOPERIDINIACEAE

Protoperidinium unipes (Balech) Balech

Protoperidinium bispinum (Schiller) Balech

$\mathrm{X}$

Protoperidinium cassum (Balech) Balech

Protoperidinium divergens (Ehrenberg) Balech

Protoperidinium sp. R. S. Bergh

PROROCENTRALES

PROROCENTRACEAE

Prorocentrum compressum

Prorocentrum gracile Schütt

Prorocentrum lima (Ehrenberg) F. Stein

$\mathrm{X}$

Prorocentrum micans Ehrenberg

$\mathrm{X}$

$\mathrm{X}$

Prorocentrum sigmoides Böhm

Prorocentrum sp.

BACILLARIOPHYTA

BACILLARIOPHYCEAE

THALASSIOPHYSALES 


\section{Continued}

CATENULACEAE

Amphora angusta Gregory

Amphora arenaria Donkin

AULACOSEIRALES

AULACOSEIRACEAE

Aulacoseira granulata (Ehrenberg) Simonsen

SURIRELLALES

SURIRELLACEAE

Campylodiscus clypeus (Ehrenberg) Ehrenbergex Kützing

Campylodiscus fastuosus Ehrenberg

Surirella febigerii $\mathrm{F}$. W. Lewis

$\mathrm{X}$

COCCONEIDALES

\section{COCCONEIDACEAE}

Campyloneis grevillei (W. Smith) Grunow \& Eulenstein

Cocconeis scutellum Ehrenberg

RHOPALODIALES

\section{ENTOMONEIDACEAE}

Entomoneis alata (Ehrenberg) Ehrenberg

$\mathrm{X}$

EUNOTIALES

EUNOTIACEAE

Eunotia didyma Grunow

NAVICULALES

DIPLONEIDACEAE

Diploneis bombus (Ehrenberg) Ehrenberg

\section{NAVICULACEAE}

Gyrosigma balticum (Ehrenberg) Rabenhorst

Navicula sp. Bory

Pleuro/Gyrosigma sp.

LYRELLALES

LYRELLACEAE

Lyrella lyra (Ehrenberg) Karajeva

$\mathrm{X}$

Navicula humerosa Brébisson ex W. Smith

BACILLARIALES

BACILLARIACEAE

Bacillaria paxillifera (O. F. Müller) T. Marsson

$\mathrm{X}$

Nitzschia lorenziana Grunow

$\mathrm{X}$

Nitzschia sigma (Kützing) W. Smith

$\mathrm{X}$

$\mathrm{X}$ 


\section{Continued}

COSCINODISCOPHYCEAE

COSCINODISCALES

AULACODISCACEAE

Aulacodiscus sp. Ehrenberg

COSCINODISCACEAE

Coscinodiscus centralis Ehrenberg

$\mathrm{X}$

Coscinodiscus oculus-iridis (Ehrenberg) Ehrenberg

RHIZOSOLENIALES

RHIZOSOLENIACEAE

Guinardia delicatula (Cleve) Hasle

MELOSIRALES

MELOSIRACEAE

Melosira dubia C. G. Kützing

$\mathrm{X}$

$\mathrm{X}$

Melosira moniliformis (O. F. Müller) C. Agardh

Melosira nummuloides C. Agardh

PARALIACEAE

Paralia sulcata (Ehrenberg) Cleve

$\mathrm{X}$

MEDIOPHYCEAE

LITHODEAMIALES

BELLEROCHEACEAE

Bellerochea horologicalisstosch

$\mathrm{X}$

$\mathrm{X}$

EUPODISCALES

EUPODISCACEAE

Odontella turgida (Ehrenberg) Kützing

Triceratium sp. Ehrenberg

$\mathrm{X}$

TOXARIALES

CLIMACOSPHENIACEAE

Climacosphaenia moniligera Ehrenberg

THALASSIOSIRALES

STHEPHANODISCACEAE

Cyclotella styllorum Brightwell

Cyclotella meneghiniana Kützing

$\mathrm{X}$

$\mathrm{X}$

THALASSIOSIRACEAE

Thalassiosira leptopus (Grunowex Van Heurck) Hasle \& G. Fryxell

Thalassiosira subtilis (Ostenfeld) Gran

$\mathrm{X}$

BIDDULPHIALES

BIDDULPHIACEAE

Isthmiaenervis Ehrenberg

$\mathrm{X}$ 


\section{Continued}

LEPTOCYLINDRALES

LEPTOCYLINDRACEAE

Leptocylindrus danicus Cleve

FRAGILARIOPHYCEAE

RHABDONEMATALES

GRAMMATOPHORACEAE

Grammatophora marina (Lyngbye) Kützing

Grammatophora oceanica Ehrenberg

LICMOPHORALES

LICMOPHORACEAE

Licmophora abbreviata C. Agardh

Licmoplora remulus Grunow

FLAGIRALIALES

FLAGILARIACEAE

Podocystis adriatica (Kützing) Ralfs

THALASSIONEMATALES

THALASSIONEMATACEAE

Thalassionema nitzschioides (Grunow) Mereschkowsky

OCHROPHYTA

DICTYOCHOPHYCEAE

DICTIOCHALES

DICTYOCHACEAE

Dictyocha fibula Ehrenberg

CHLOROPHYTA

CHLOROPHYCEAE

SPHAEROPLEALES

SCENEDESMACEAE

Scenedesmus bijuga (Turpin) Lagerheim

Scenedesmus quadricauda (Turpin) Brébisson

$\mathrm{X}$

TREBOUXIOPHYCEAE

TREBOUXIOPHYCEAE (ordo ircertaesedis)

TREBOUXIOPHYCEAE (incertaesedis)

Crucigenia fenestrata (Schmidle) Schmidle

$\mathrm{X}$

CHAROPHYTA

CONJUGATOPHYCEAE

DESMIDIALES

CLOSTERIACEAE

Closterium sp. Nitzsch ex Ralfs

DESMIDIACEAE

Staurastrum sp. MeyenexRalfs

X 
Table S2. Factorial loads of the PCA analysis of first four components. In red and blue positive and negative correlations, respectively.

\begin{tabular}{|c|c|c|c|c|}
\hline Parameters & F1 & F2 & F3 & F4 \\
\hline Secchi & 0.794 & 0.015 & 0.027 & -0.309 \\
\hline $\mathrm{T}^{\circ} \mathrm{C}$ & 0.377 & -0.659 & 0.194 & -0.024 \\
\hline Salinity & 0.941 & -0.035 & -0.089 & -0.010 \\
\hline DO & 0.901 & 0.095 & -0.242 & 0.114 \\
\hline $\mathrm{pH}$ & 0.813 & -0.138 & 0.153 & -0.140 \\
\hline $\mathrm{NH}_{4}^{+}$ & -0.603 & 0.138 & 0.551 & -0.014 \\
\hline $\mathrm{NO}_{2}^{-}$ & -0.552 & -0.408 & -0.527 & -0.178 \\
\hline $\mathrm{NO}_{3}^{-}$ & -0.652 & -0.182 & -0.429 & 0.028 \\
\hline $\mathrm{PO}_{4}^{-}$ & -0.710 & -0.176 & 0.393 & -0.301 \\
\hline $\mathrm{SiO}_{2}^{-}$ & -0.676 & 0.331 & -0.371 & 0.215 \\
\hline Суа & -0.571 & -0.307 & 0.379 & 0.075 \\
\hline $\mathrm{Bac}$ & -0.005 & -0.550 & -0.076 & 0.641 \\
\hline Chl & -0.232 & -0.418 & -0.320 & -0.607 \\
\hline Rainfall & -0.176 & 0.800 & -0.086 & -0.138 \\
\hline
\end{tabular}

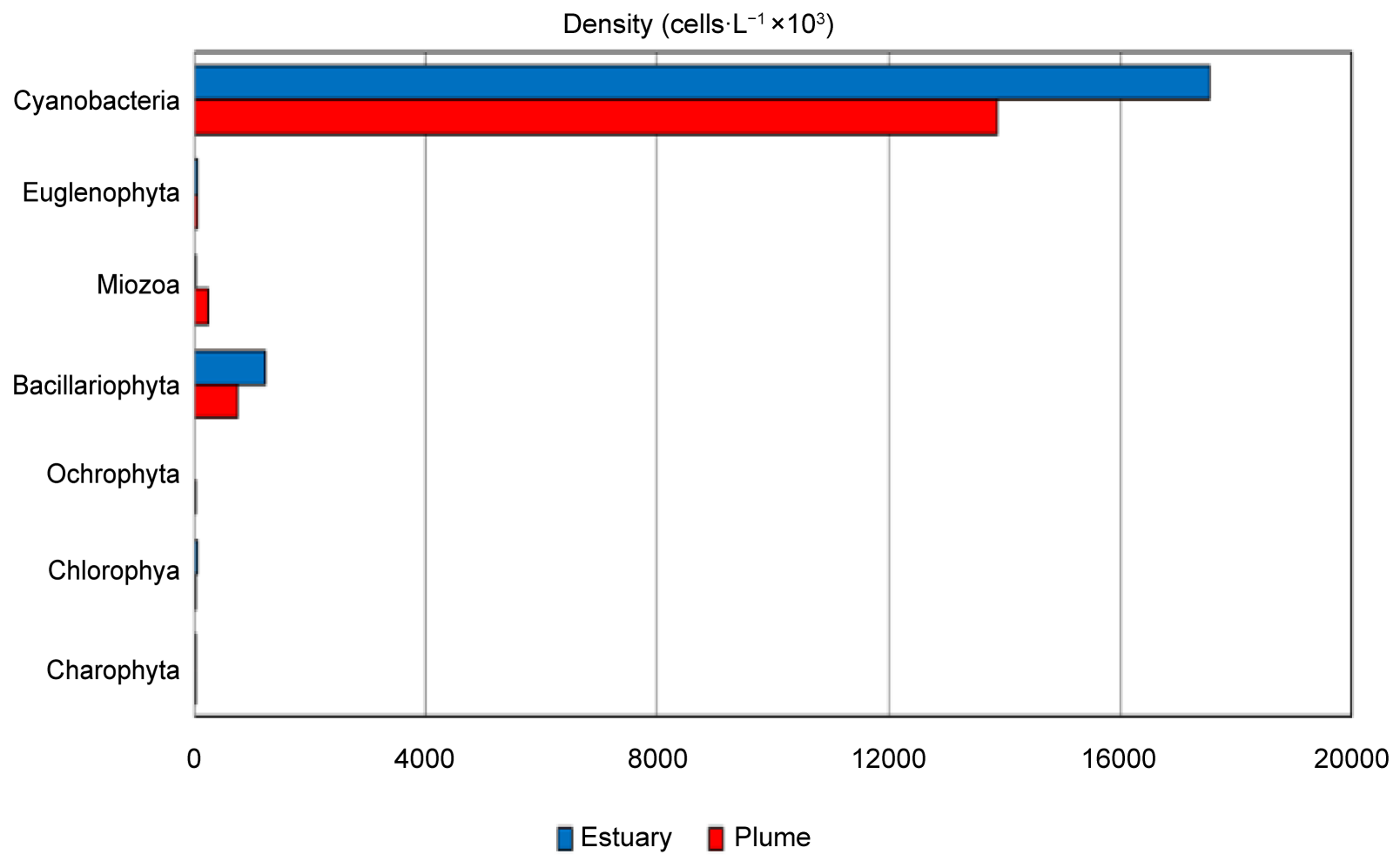

Figure S1. Total density of the groups in the studied areas. 


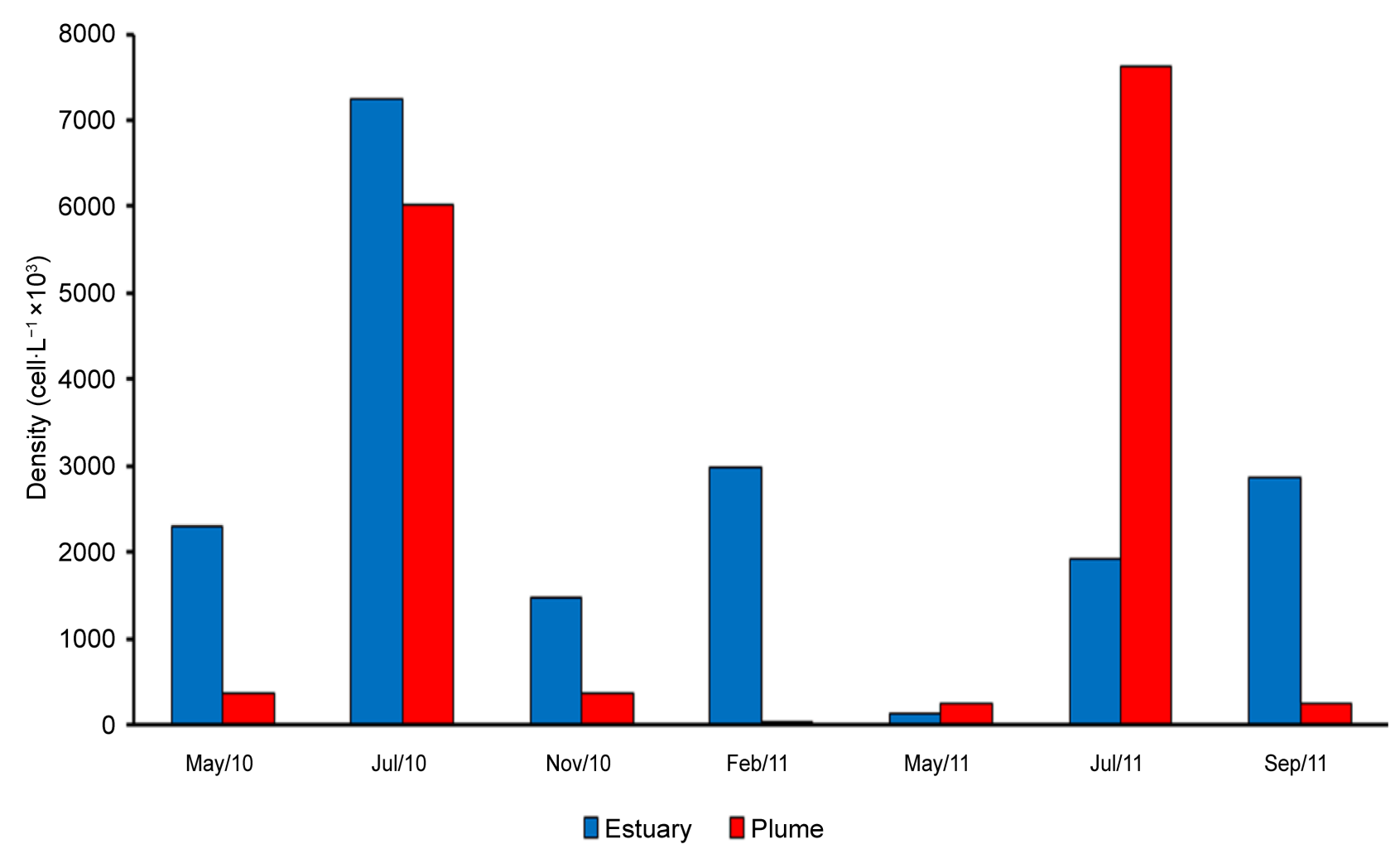

Figure S2. Total density for the months in the studied areas.

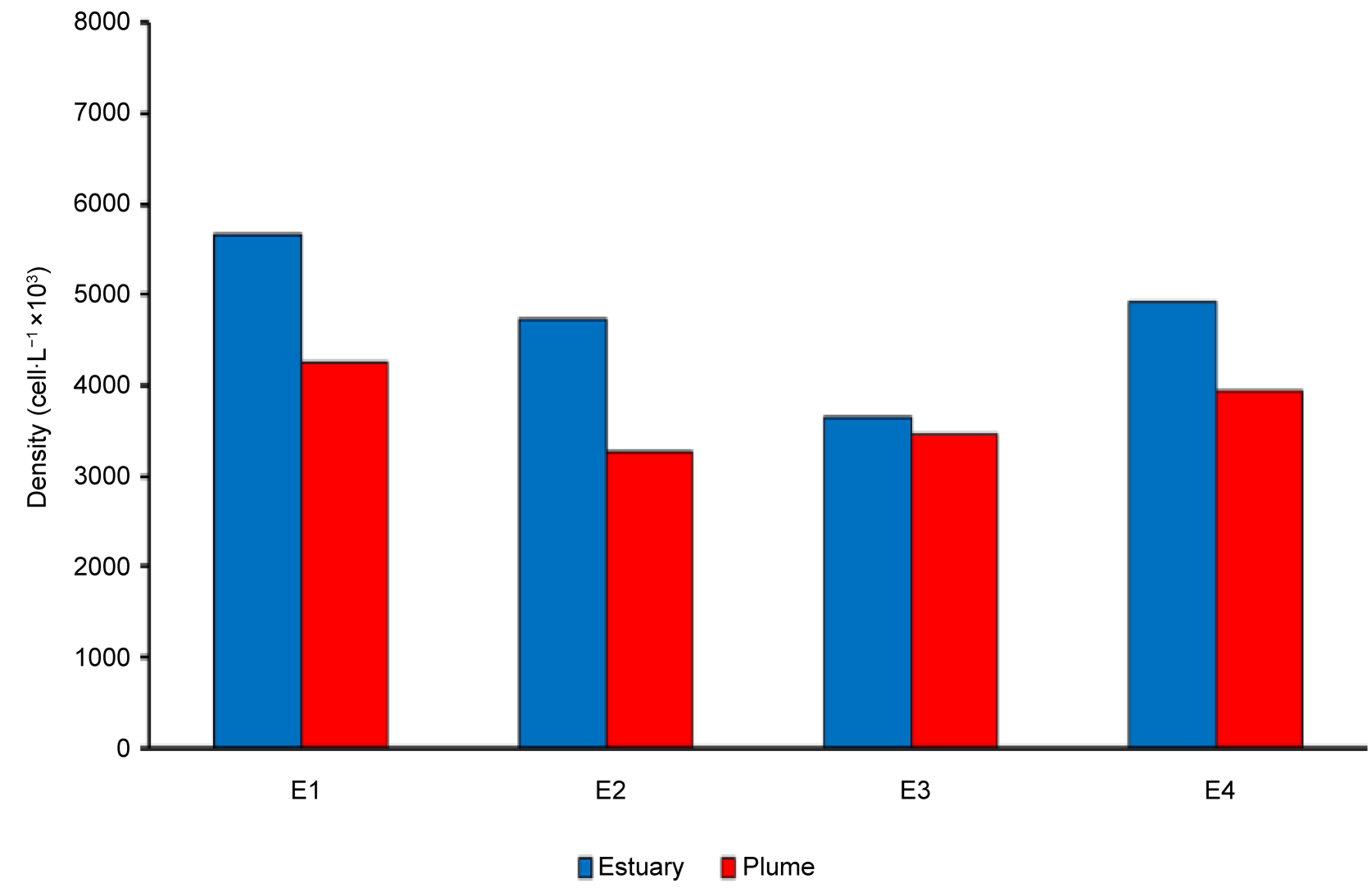

Figure S3. Total density for the stations in the studied areas. 


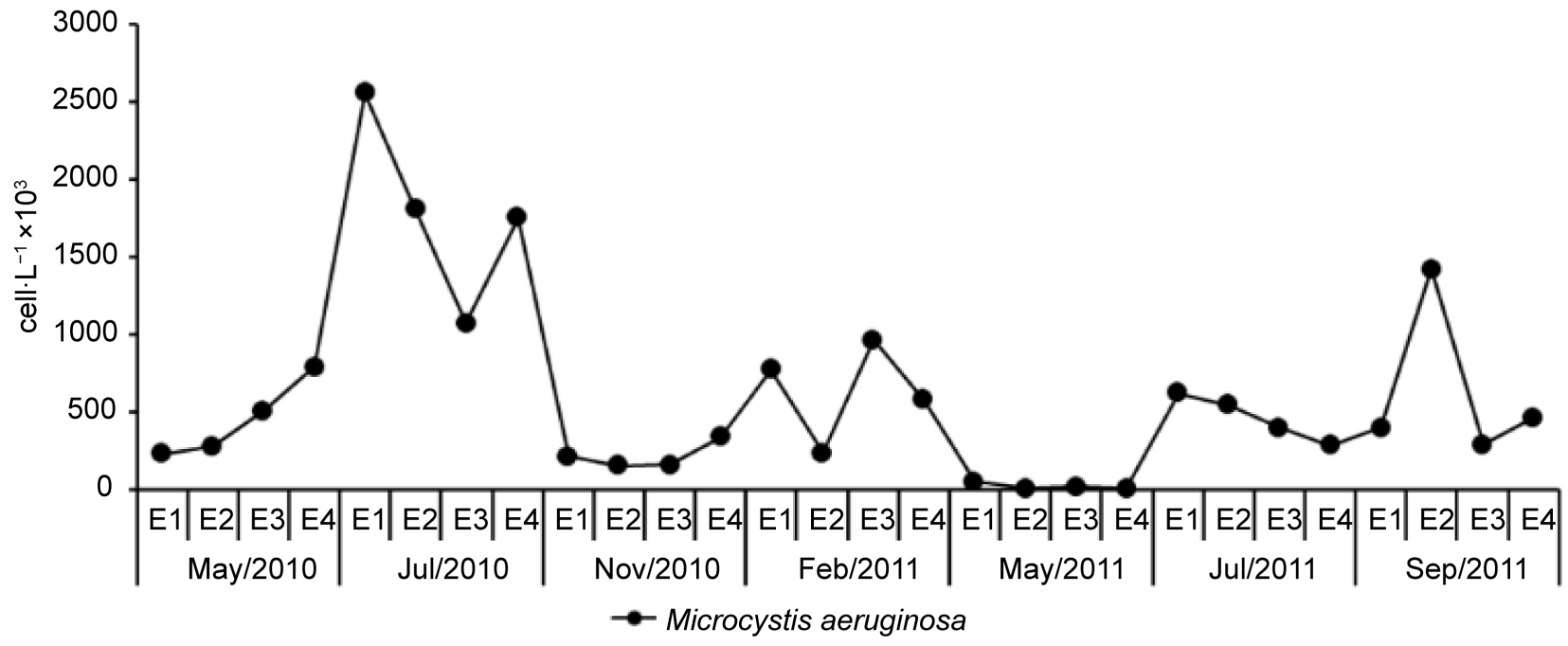

Plume

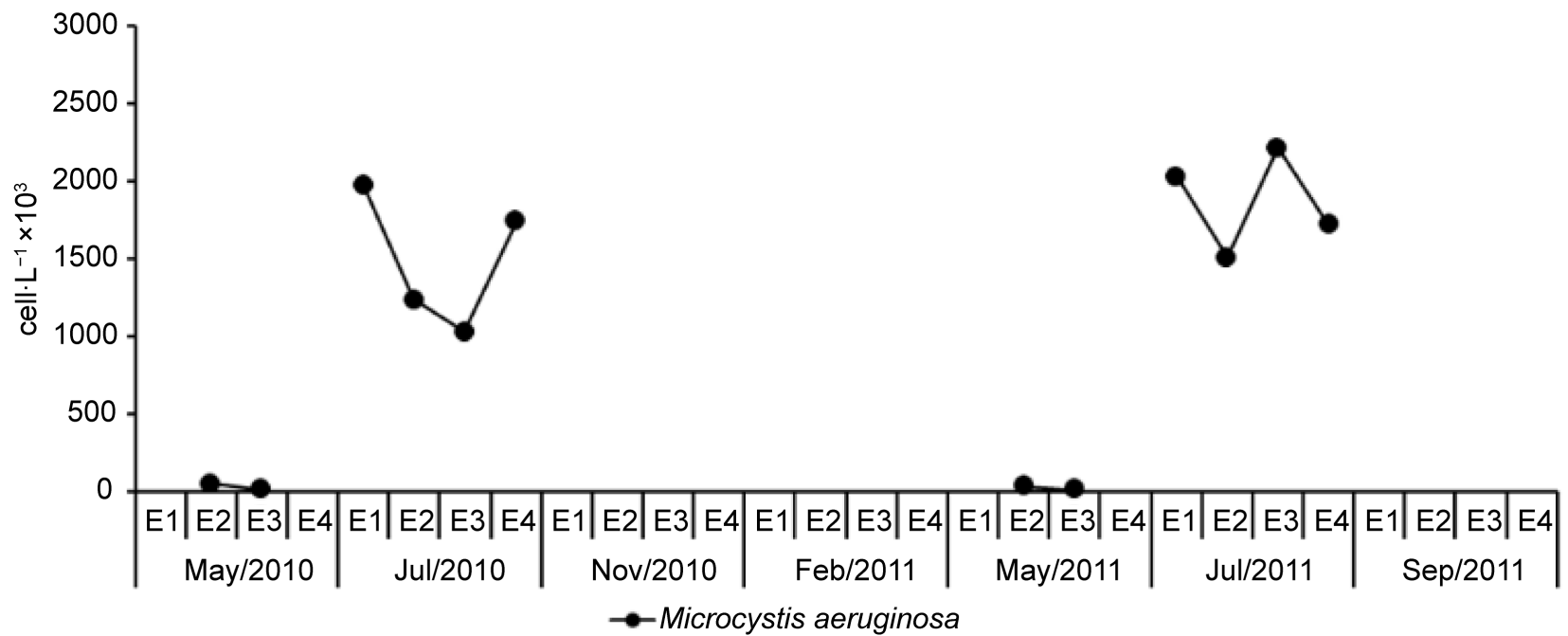

Figure S4. Total density of Microcystis aeruginosa. 
Submit or recommend next manuscript to SCIRP and we will provide best service for you:

Accepting pre-submission inquiries through Email, Facebook, LinkedIn, Twitter, etc. A wide selection of journals (inclusive of 9 subjects, more than 200 journals)

Providing 24-hour high-quality service

User-friendly online submission system

Fair and swift peer-review system

Efficient typesetting and proofreading procedure

Display of the result of downloads and visits, as well as the number of cited articles Maximum dissemination of your research work

Submit your manuscript at: http://papersubmission.scirp.org/

Or contact oje@scirp.org 